LIFE SCIENCES CONTRIBUTIONS

ROYAL ONTARIO MUSEUM

NUM B E R 83

Evolutionary Trends in

Longipinnate Ichthyosaurs

with Particular Reference to

the Skull and Fore Fin

C. Mc GOW A N

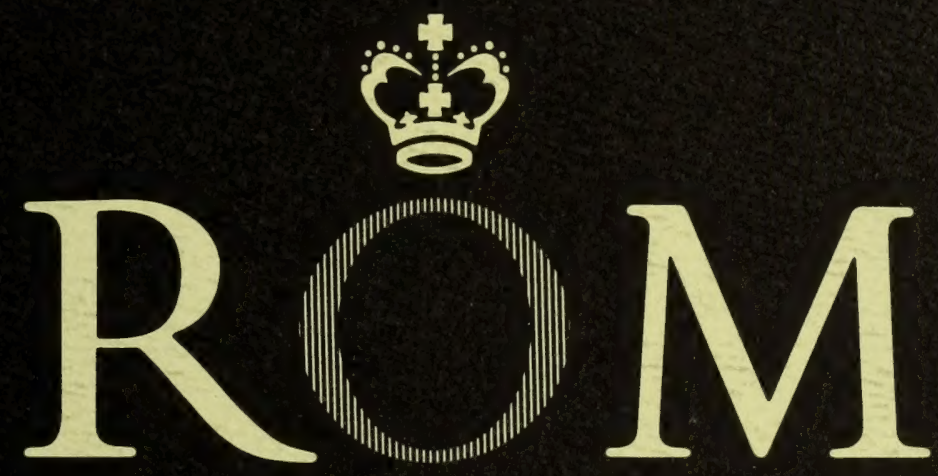





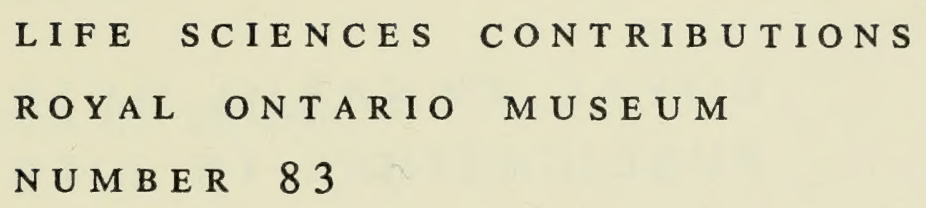

C. M c G O W A N

\section{Evolutionary Trends in Longipinnate Ichthyosaurs with Particular Reference to the Skull and Fore Fin}




\section{ROYAL ONTARIO MUSEUM PUBLICATIONS IN LIFE SCIENCES}

The Royal Ontario Museum publishes three series in the Life Sciences:

LIFE SCIENCES CONTRIBUTIONS, a numbered series of original scientific publications, including monographic works.

LIFE SCIENCES OCCASIONAL PAPERS, a numbered series of original scientific publications, primarily short and usually of taxonomic significance.

LIFE SCIENCES MISCELlANEOUS PUBLICATIONS, an unnumbered series of publications of varied subject matter and format.

All manuscripts considered for publication are subject to the scrutiny and editorial policies of the Life Sciences Editorial Board, and to review by persons outside the Museum staff who are authorities in the particular field involved.

LIFE SCIENCES EDITORIAL BOARD, 1972-1973

Editors: D. BARR

J. R. TAMSITT

CHRISTOPHer MCGowan is Assistant Curator, Department of Vertebrate Paleontology, Royal Ontario Museum, and Assistant Professor, Department of Zoology, University of Toronto.

PRICE: $\$ 2.00$

(C) The Royal Ontario Museum, 1972

100 Queen's Park, Toronto, Canada

PRINTED AT HANSON \& EDGAR LIMITED, KINGSTON, ONTARIO 


\section{Contents}

Abstract, 1

Introduction, 2

Materials and Methods, 7

The Genus Platypterygius, 15

The Evolution of Longipinnate Ichthyosaurs, 22

Evolution of the Longipinnate Skull, 22

Evolution of the Longipinnate Body, 27

Evolution of the Longipinnate Fore Fin, 30

Size Ranges in Longipinnates, 31

Conclusions, 33

Acknowledgments, 36

Literature Cited, 37 
Digitized by the Internet Archive in 2011 with funding from University of Toronto 


\title{
Evolutionary Trends in Longipinnate Ichthyosaurs with Particular Reference to the Skull and Fore Fin
}

\begin{abstract}
The history of ichthyosaurs is briefly traced from the Middle Triassic to the Upper Cretaceous. Platypterygius Von Huene, the only Cretaceous representative, is compared with other longipinnates, including Cymbospondylus petrinus Leidy, Middle Triassic; Proteosaurus platyodon (Conybeare), Lower Liassic; and Stenopterygius quadriscissus (Quenstedt), Upper Liassic.

Several evolutionary trends occur in the skull and fore fin of ichthyosaurs (McGowan, 1972) and whereas some of these trends are well advanced in Platypterygius, others are retarded. The diameters of the orbit and internal sclerotic ring are small in Platypterygius, as in Cymbospondylus Leidy, whereas the orbit lies more posteriorly, and is in this respect comparable with Stenopterygius Jaekel. Maxillary reduction in Platypterygius is intermediate between Cymbospondylus and Stenopterygius. The fore-fin trend towards an increase in the total number of digits is more advanced in Platypterygius than in any other longipinnate ichthyosaur, and the fin is unique for the presence of three pre-axial accessory digits. Platypterygius also differs from other longipinnates in its body proportions, the skull is relatively larger, the tail fin much smaller.

An attempt to reconstruct the locomotor habits of Platypterygius indicate that the fore fins were used for propulsion, unlike most ichthyosaurs, and it is suggested that speed and manoeuverability may have been inferior to Jurassic longipinnates.
\end{abstract}

Longipinnate evolution is discussed, and an attempt is made to quantify the rates of cranial evolution. Rates of change were highest during the Liassic and lowest during the long, post-Liassic interval. The remarkable homogeneity of ichthyosaurian body form during the Cretaceous, exemplified by the single genus Platypterygius, supports the conclusion that the rate of evolutionary change was at its lowest level. Loss of adaptive plasticity at a time when a new competitor, the mosasaur, was rapidly evolving is suggested as a possible cause of extinction. 


\section{Introduction}

A recent investigation of Cretaceous ichthyosaurs (McGowan, in press, Contr. Geol.) demonstrated a remarkable homogeneity within the known material, all referrable to the single genus Platypterygius, which is a longipinnate. The distinction between latipinnate and longipinnate ichthyosaurs was discussed elsewhere (McGowan, 1972), but it would be useful to summarize the main points.

Latipinnate ichthyosaurs have fore fins with four distal carpals, each supporting a primary digit, whereas longipinnates have only three distal carpals and therefore only three primary digits. The total digital count is increased in both groups by the presence of accessory digits, and in latipinnates by digital bifurcation also. The evolutionary trend towards an increase in the total digital count is more rapid in latipinnates than in longipinnates, so that latipinnates usually have higher counts than their longipinnate contemporaries. The two groups can also be distinguished on cranial characters, latipinnates having relatively larger orbital and internal sclerotic ring diameters and smaller maxillae than do longipinnates.

Platypterygius was widely distributed geographically and geologically. It has been found in England, Germany, south-western Russia, north-eastern India, western United States, Argentina, north-central Queensland and Western Australia and was probably worldwide in distribution. Ranging from the Neocomian to the Cenomanian (to the Santonian if the Dandaragan Chalk is of the same age as the Gingin Chalk, both of Western Australia; see Teichert and Matheson, 1944, and McWhae et al., 1958), Platypterygius existed from the Lower Cretaceous to the Upper Cretaceous, a duration of about 45 million years. It is noteworthy that Platypterygius, the last of the ichthyosaurs, was a longipinnate, the last known latipinnate (Ophthalmosaurus Seeley) having apparently become extinct during the late Jurassic.

Some cranial trends seen during ichthyosaurian evolution were weakly expressed in Platypterygius and had barely progressed beyond the stage exemplified by the earliest known longipinnate, Cymbospondylus, Middle Triassic, North America. Before discussing Platypterygius, a brief review of the geological history of the Ichthyosauria is warranted.

Unfortunately, the fossil record of the ichthyosaurs is discontinuous, and remains are known from six horizons: Middle Triassic, Upper Triassic, Lower Liassic, Upper Liassic, Lower Cretaceous, and the boundary of the Lower Cretaceous/Upper Cretaceous. The earliest material is from the Middle Triassic of Nevada and Spitzbergen. The Nevada locality yielded the earliest known longipinnate genus, Cymbospondylus, which is known from several specimens, including some well-preserved skulls and a nearly complete skeleton. Unfortunately the structure of the fore fin is incomplete (Fig. 1 A) but resembles that of Merriamia Boulenger (Fig. 1 E) a longipinnate from the Upper Triassic of California (see Merriam, 1908). Occurring at the same locality as Cymbospondylus was a partial skull of an obscure reptile described by Merriam in 1906 as Omphalosaurus. 

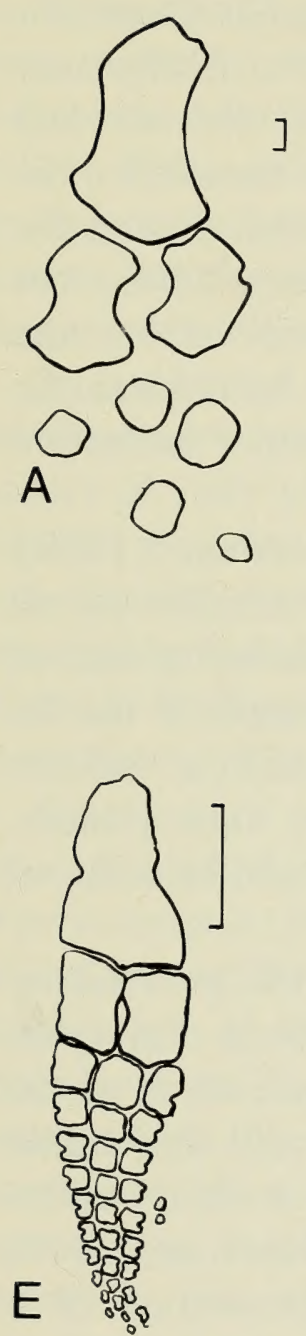
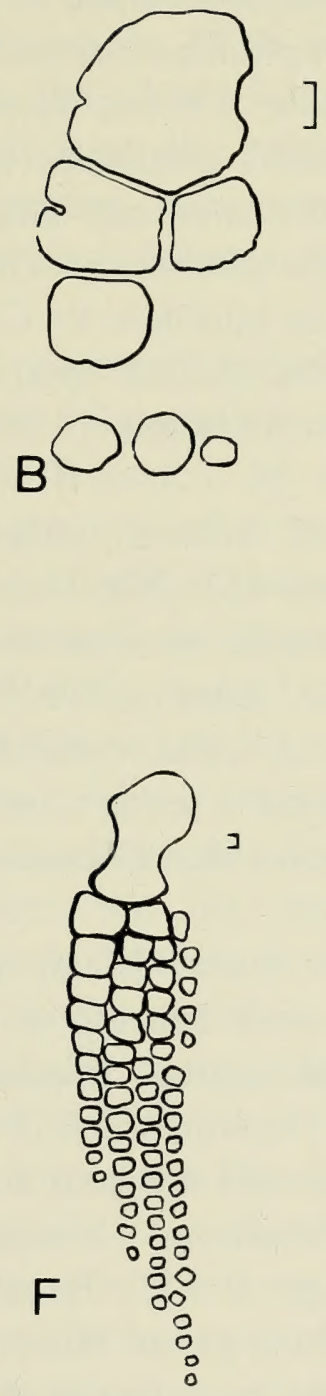

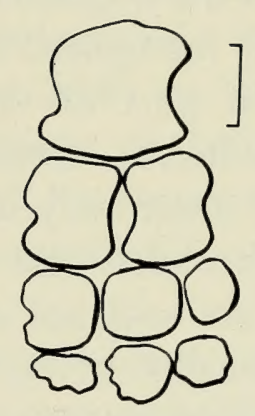

C

D

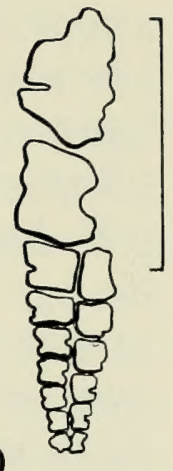

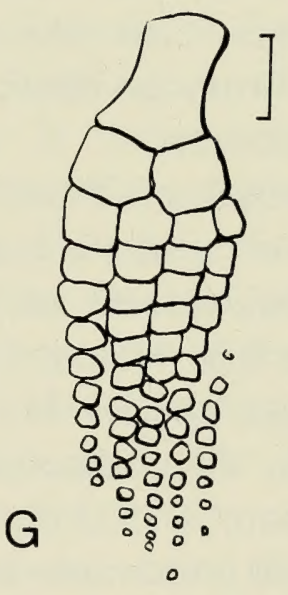

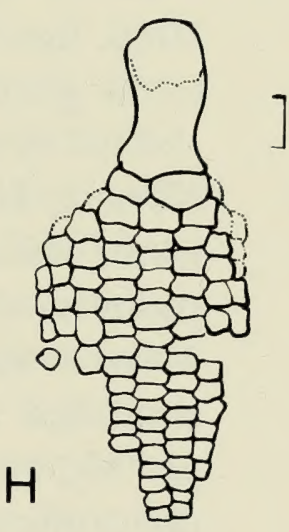

Fig. 1. Fore fins of longipinnate ichthyosaurs. For ease of comparison each fin is drawn as if it were a left fin in dorsal view. A. Cymbospondylus petrinus Middle Triassic, Nevada, U.S. (after Merriam, 1908, p. 64); B. Shastasaurus osmonti Upper Triassic, California, U.S. (after Merriam, 1908, p. 64); c. Delphinosaurus perrini Upper Triassic, California, U.S. (after Merriam, 1908, p. 64); D. Toretocnemus californicus Upper Triassic, California, U.S. (after Merriam, 1908, p. 128); E. Merriamia zitteli Upper Triassic, California, U.S. (after Merriam, 1908, p. 64); F. Eurhinosaurus longirostris Upper Liassic, Germany (from Hauff, 1953, pl. 21); G. Stenopterygius quadriscissus Upper Liassic, Germany, BMNH R4086; н. Platypterygius platydactylus Lower Cretaceous, Germany (after Broili, 1907, fig. 13). Scale $=4 \mathrm{~cm}$.

Characteristic of the genus are the blunt, button-like teeth set in several rows. Merriam (1906) did not consider the material to be ichthyosaurian and concluded that it was probably best to place it in a group of its own. In a description of Middle Triassic ichthyosaurs from Spitzbergen, Wiman (1910) described some jaw fragments that possessed teeth similar to those of Omphalosaurus. Wiman tentatively referred these jaw fragments, as well as other material, to a new ichthyosaurian genus, Pessopteryx Wiman. Merriam (1911) criticised Wiman's inclusion of these jaw fragments in the Ichthyosauria. In 1916 Wiman agreed with Merriam 
and concluded that the fragments should be referred to the genus Omphalosaurus. Thus it was recognised that Omphalosaurus was not an ichthyosaur but merely formed part of the Middle Triassic faunas of Nevada and Spitzbergen. Nonetheless, Omphalosaurus continues to be considered an ichthyosaur, albeit incorrectly. Omphalosaurus has been compared with the placodonts, rhynchosaurs, and with the plesiosaurs (Merriam, 1906) but its true affinities are still not clear. In addition to Cymbospondylus, the Middle Triassic locality of Nevada has yielded two more ichthyosaurian species, Cymbospondylus (?) natans Merriam (1908) and Phalarodon fraasi Merriam (1910).

The type material of the species $C$. natans, which Merriam (1908) only tentatively referred to the genus Cymbospondylus, consists of an incomplete fore fin, which, Merriam noted, is somewhat similar to that of the latipinnate genus Mixosaurus Baur. Wiman (1916) compared the fin of $C$. natans with that of Mixosaurus nordenskioldii (Hulke), Middle Triassic, Spitzbergen, and demonstrated a close similarity (see Wiman, 1916, figs. 1, 2). From the above it seems that $C$. natans should be referred to the genus Mixosaurus.

The type material of Phalarodon fracisi Merriam, Middle Triassic, Nevada, consists of a small, partial skull bearing pronounced dimorphic teeth. The anteriomost teeth are almost conical, whereas the crowns of the posterior teeth are flat. Wiman (1916) compared $P$. fraasi with the Middle Triassic Spitzbergen species $M$. nordenskioldii and found a close correspondence between their dimorphic dentitions (compare Merriam, 1910, pl. 40, and Wiman, 1910, pl. 5, figs. 9-13). Because possession of a dimorphic dentition is characteristic of the genus Mixosaurus (see Merriam, 1908 ) I conclude that $P$. fraasi should be referred to that genus. Wiman (1916) also noted that $M$. natans (Merriam) might represent the skull of $M$. fraasi (Merriam) as they occurred together at the same horizon, and this seems to be a reasonable conclusion. The Middle Triassic locality of Nevada has thus yielded two well-known genera, the longipinnate genus Cymbospondylus, and the latipinnate genus Mixosaurus.

The first description of ichthyosaurian material from Spitzbergen (Middle Triassic) was given by Hulke (1873), who described two new ichthyosaurian species, Ichthyosaurus nordenskioldii and I. polaris. In each the type material was fragmentary, but additional material was described by Wiman (1910), who referred the first species to the genus Mixosaurus and the second to a new genus, Pessosaurus. Wiman (1910) also described a second new genus, Pessopteryx, to which he referred four new species, $P$. artica, $P$. pinguis, $P$. minor, and $P$. nisseri. Whereas $M$. nordenskioldii (Hulke) is represented by an amount of determinate material, Pessosaurus polaris (Hulke) and the four species of Pessopteryx are poorly known. Whether Pessopteryx and Pessosaurus are latipinnate or longipinnate cannot be determined. In 1929 Wiman described a new ichthyosaur from Spitzbergen which he referred to a new species, Grippia longirostris. More adequate figures were given by Wiman in 1933 and it can be seen that $G$. longirostris possessed the button-like teeth that are characteristic of Mixosaurus (see Wiman, 1933, pl. 1). There seems little doubt that this 
material should be referred to the genus Mixosaurus, and this suggestion was made by von Huene in 1930 in a bibliographic reference (Neues Jahrbuch, Min. Geol. Pal., Vol. 3, 1930, p. 264) to Wiman's paper of 1929. Thus, recovered from the Middle Triassic of Spitzbergen are two inadequately known genera, Pessosaurus and Pessopteryx, and two wellknown latipinnate species, Mixosaurus nordenskioldii (Hulke) and $\boldsymbol{M}$. longirostris (Wiman).

A number of well-preserved skeletons of the small latipinnate species Mixosaurus cornalianus (Bassani) have been recovered from the Bassano shales of Italy (Upper Triassic). M. cornalianus is similar to $M$. nordenskioldii but for the absence of a post-axial accessory digit. M. atavus (Quenstedt) from the Middle Triassic of Germany is a well-represented species similar to $M$. cornalianus. Some ichthyosaurian vertebrae from the Triassic of Timor, Indonesia, have been referred to the genus Mixosaurus (see Broili, 1931, von Huene, 1936).

Four genera are known from the Upper Triassic of California, Merriamia Boulenger, Shastasaurus Merriam, Delphinosaurus Merriam, and Toretocnemus Merriam, but the material is incomplete in every one. Furthermore, in only Merriamia is the fore fin complete, so that our knowledge of these ichthyosaurs is altogether fragmentary. Merriamia possessed an unmistakable longipinnate fore fin and so did Delphinosaurus (see Fig. 1). The fore fin of Toretocnemus appears to be similar to that of Merriamia (compare Fig. 1D, E). It is unlikely that there were more than three digits in Toretocnemus because the second digit lies partly in line with the position once occupied by the second epipodial, leaving only enough space to accommodate one more digit. The fore fin of Toretocnemus is therefore concluded to be longipinnate. Although the type material of Toretocnemus and Merriamia represents small individuals (fore fin lengths of approximately $5 \mathrm{~cm}$ and $12 \mathrm{~cm}$, respectively), Delphinosaurus appears to be moderate in size (fore fin length in excess of 16 $\mathrm{cm}$ ), and Shastasaurus (like Cymbospondylus) is extremely large (fore fin length in excess of $40 \mathrm{~cm}$ ). From the American Upper Triassic, then, are four genera representing at least nine species. In numbers of specimens and state of preservation, however, no horizon can compare with the Lower Jurassic of Europe.

Most ichthyosaurs that have been found are from the Liassic deposits of England and Germany. From the Lower Liassic of England are four latipinnate species that belong to the genus Ichthyosaurus: I. communis Conybeare, I. breviceps Owen, I. conybeari Lydekker, and I. tenuirostris Conybeare. All four species are represented by complete skeletons. Occurring with these latipinnates are at least three longipinnate species, including Proteosaurus platyodon (Conybeare) and two new species of the genus Proteosaurus that have not yet been described. Upper Liassic ichthyosaurs are not frequently found in England and only one species, Stenopterygius (?) acutirostris (Owen), is well known.

The Upper Liassic quarries of Holzmaden, Germany, have yielded some of the best preserved ichthyosaurs. All appear without exception to 
be longipinnate, and most are probably referrable to the genera Stenopterygius Jaekel and Eurhinosaurus Abel. Among the better known species are $S$. quadriscissus (Quenstedt), the most common, $S$. crassicostatus (Fraas), S. megacephalus von Huene, S. hauffianus von Huene, S. megalorhinus von Huene, and $S$. distinteger von Huene. Eurhinosaurus, distinct from Stenopterygius, is characterised by a short lower jaw that does not extend to the tip of the extremely long and tenuous snout. The fins are long and narrow, and the angle of the tail bend exceeds that of all other longipinnates. Only two species of this genus are known, E. longirostris (Jaeger) and E. hueni Swinton.

After the relative abundance of ichthyosaurs in the Upper Liassic, little material is seen again until the Late Jurassic, where the latipinnate genus Ophthalmosaurus is found. Ophthalmosaurus, well represented in the Oxford Clay of England, is moderate in size (about 4 metres in total body length). Ophthalmosaurs are also found in the Upper Jurassic Sundance formation of the western U.S. and are usually referred to the genus Baptanodon, but further research into the group may well demonstrate the inappropriateness of this allocation. The species described by Rusconi (1948) from the Jurassic of Argentina, Ancanamunia mendozana is based upon an incomplete skeleton, but the humerus is well preserved (Rusconi, 1948, fig. 65) and has three distal facets as in Ophthalmosaurus (Andrews, 1910, fig. 36). Furthermore, the single phalanx figured (Rusconi, 1948, fig. 69) has a rounded outline, like that of Ophthalmosaurus, and it seems certain that Rusconi's species should be referred to this genus.

Save for isolated teeth, vertebral centra, and other fragmentary material little more of ichthyosaurian history is seen until early in the Cretaceous when Platypterygius appeared. Platypterygius was a fairly large longipinnate, with an adult body size of about 7 metres. The skull possessed some characteristics that had barely progressed beyond the evolutionary stage represented by Cymbospondylus of the Middle Triassic, and its fore fins were unique (Fig. 1H). Pre-axial accessory digits numbered three, giving rise to a total digital count of eight, which is unprecedented in the longipinnate line. The fore fin was consequently broad, the base narrow, and was primarily used for sculling. Platypterygius was examined in some detail and will be compared with its predecessors in an attempt to gain an insight into ichthyosaurian evolution. 


\section{Materials and Methods}

Data were obtained by direct measurement of 22 longipinnates and by indirect measurement from photographs of an additional 19. Of these specimens, 10 were from the Middle and Upper Triassic of the western U.S., 24 from the Lower Jurassic of Europe, and seven from the Lower Cretaceous of Australia and the western U.S. The majority of specimens were judged to be adult inasmuch as they were either close to the maximum size recorded for the particular taxon or they were large (skull length exceeding one metre). Three of the specimens from the English Lower Jurassic (Hettangian and Sinemurian) belong to a new species of the genus Proteosaurus, and as this species has not yet been described, it will be referred to throughout as Proteosaurus sp. *

All measurements were recorded in centimetres, using vernier calipers where possible, and expressed to the first decimal place. When measurements were taken from photographs, the estimated error (empiric) was not in excess of $10 \%$. Measurements taken from the skull are shown in Fig. 2 and recorded in Table 1. Ratios derived from these measurements are: Diameter of orbit to the length of jaw; internal diameter of sclerotic ring to the diameter of orbit; length of external naris to the diameter of orbit; distance between tip of snout and anterior border of external naris to the length of jaw; and, distance between tip of snout and anterior tip of maxilla to the length of jaw. Terminology used in describing post-cranial structures is given in Fig. 3 together with those measurements recorded. Note that the length of the fore fin is measured from the most distal point of the humerus to the most distal phalanx.

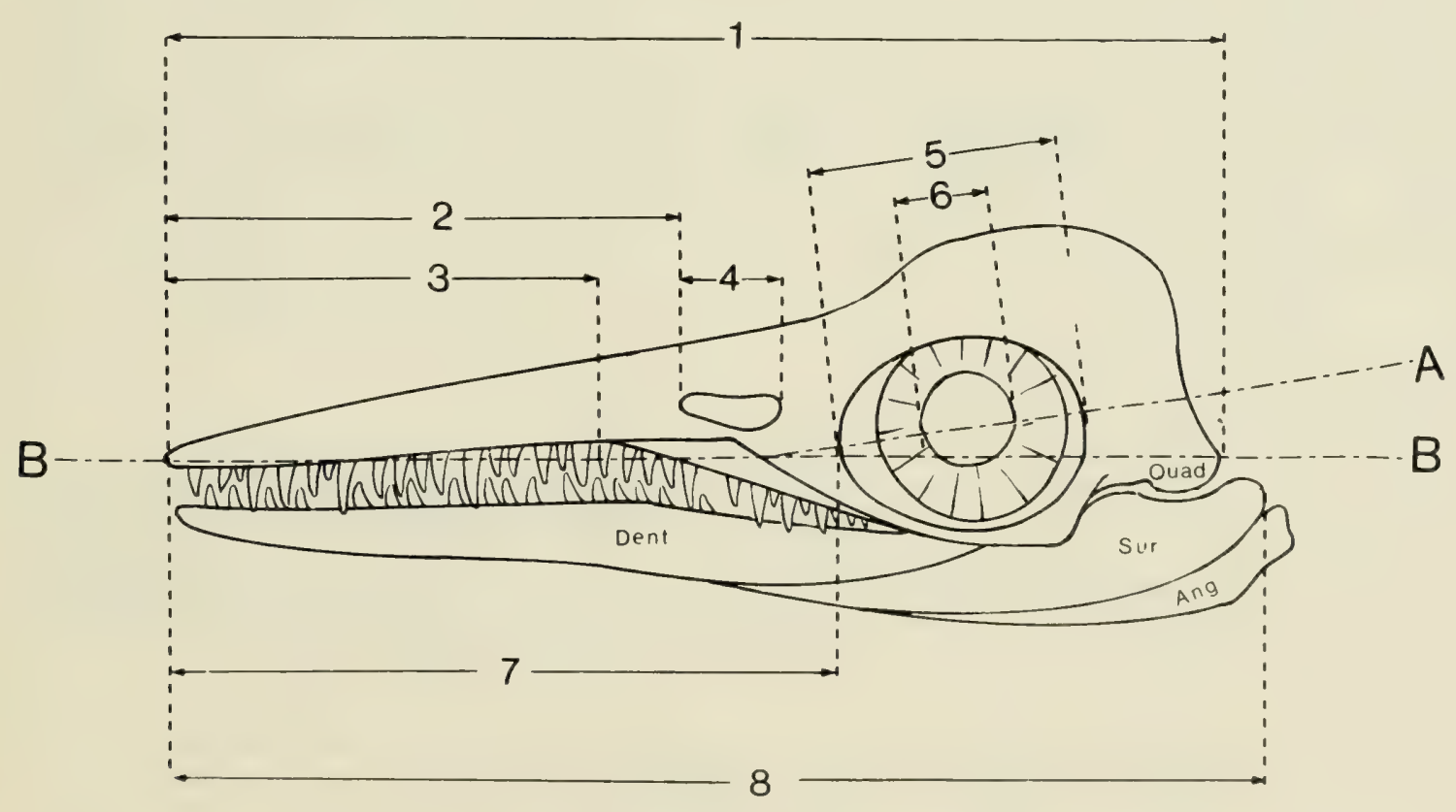

Fig. 2. Diagram of an ichthyosaur skull showing those continuous variates that were recorded. 1 - length of skull; 2 - distance between tip of snout and the anterior border of the external naris; 3 - distance between tip of snout and the anterior tip of the maxilla; 4 - length of external naris; 5 - diameter of orbit; 6 - internal diameter of sclerotic ring; 7 - length of snout; 8 - length of jaw. Ang = angular; Dent $=$ Dentary; Quad $=$ quadrate; Sur $=$ surangular. 

Length of external
naris/diameter of orbit

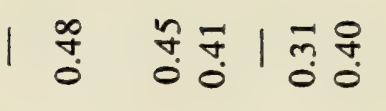

Distance between tip of snout and anterior boundary of external naris/length of jaw

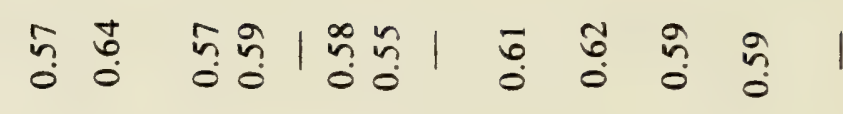

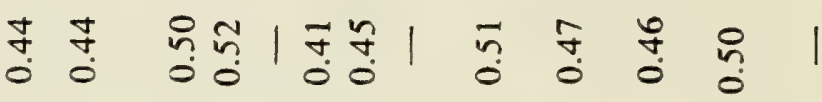
of snout and anterior tip of maxilla/length of jaw

Length of snout/ length of jaw

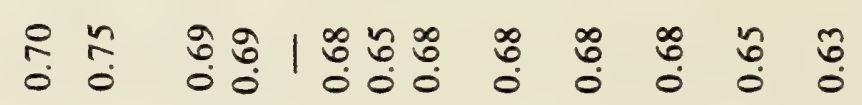

Internal diameter of sclerotic ring/ diameter of orbit

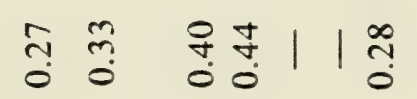

$$
\begin{aligned}
& \text { Diameter of } \\
& \text { orbit/length } \\
& \text { of jaw }
\end{aligned}
$$

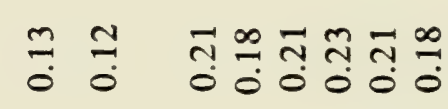

ஸ்

Specimen number

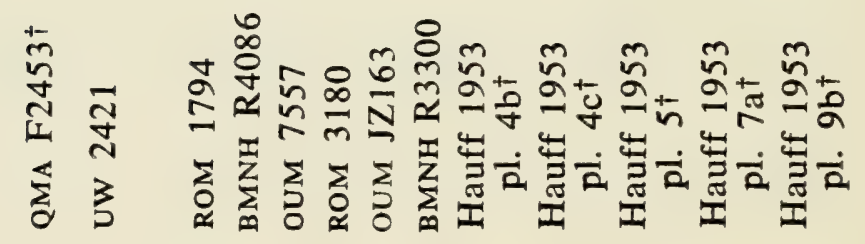

Species

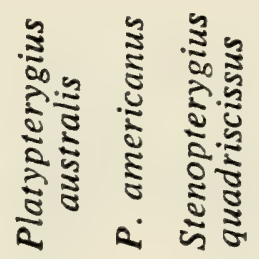




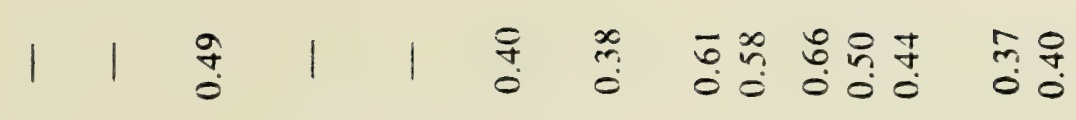

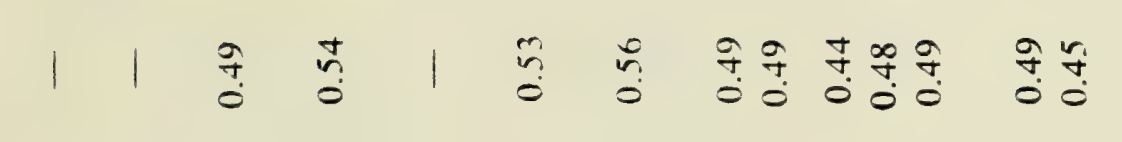

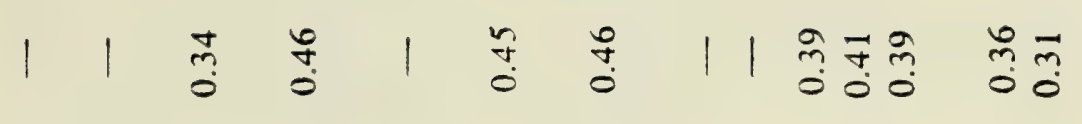

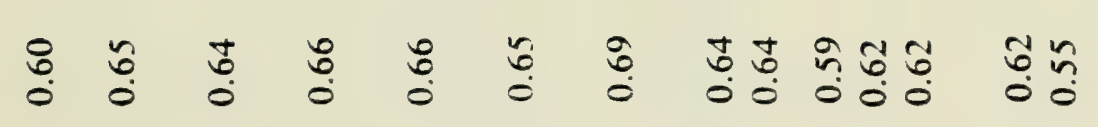

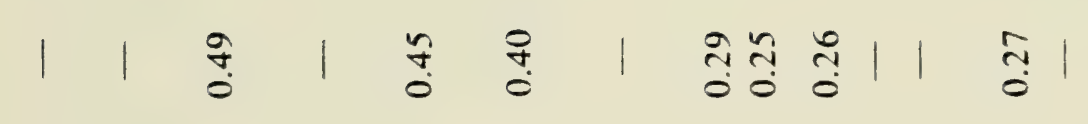

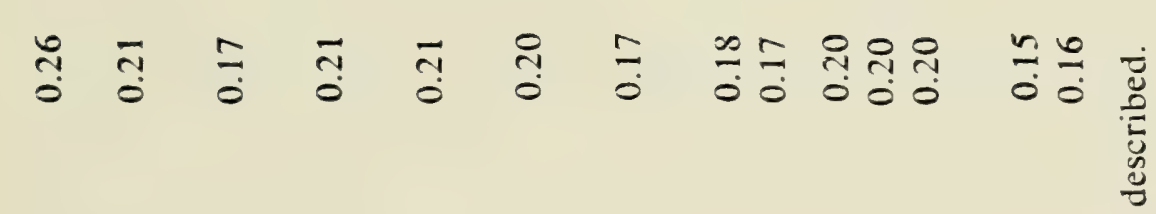

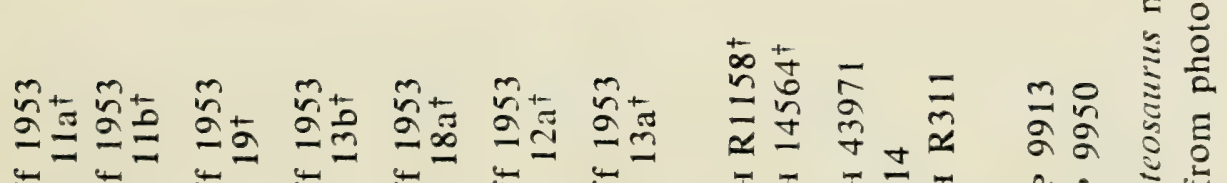

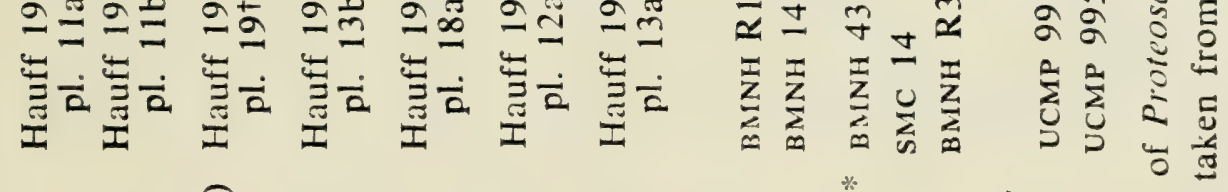

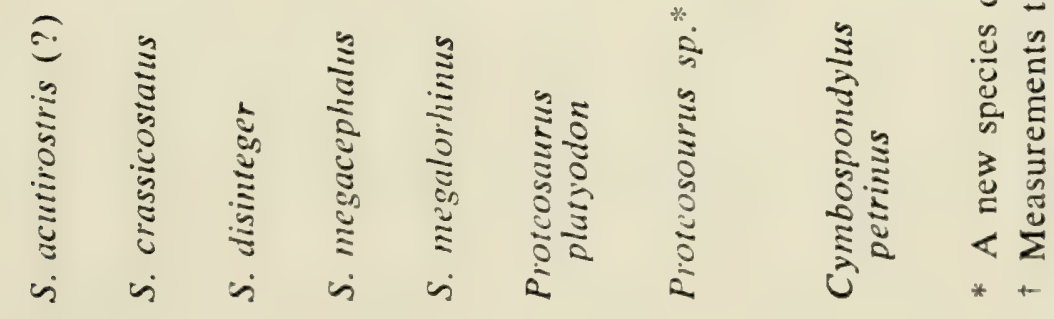




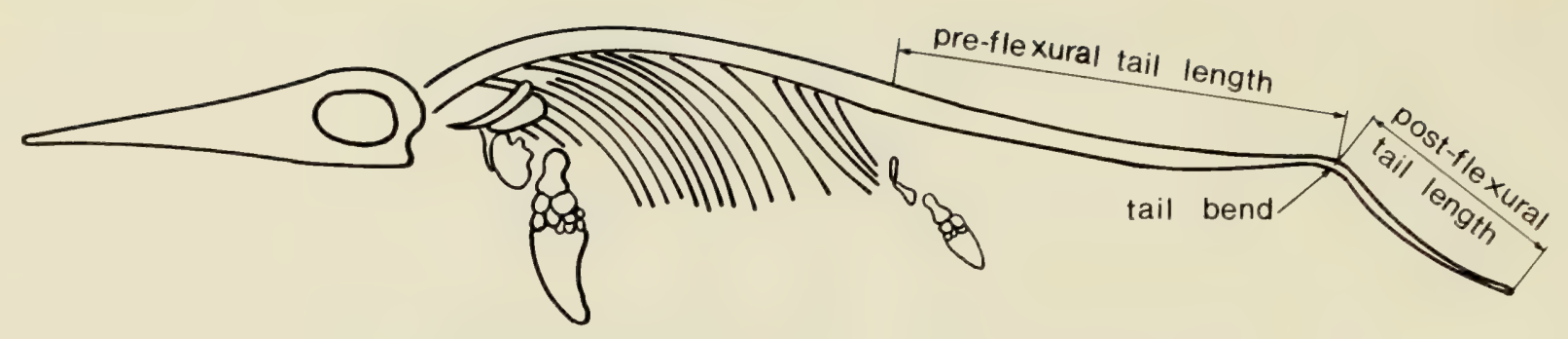

Fig. 3. Generalised body of an ichthyosaur showing characters referred to in the text.

A graphic method was used to trace the evolutionary changes occurring in the skull during the geological history of longipinnates. First, all cranial data for a given taxon were collected, and mean values for the individual ratios were calculated. A straight line representation of the skull of each taxon was then produced in unit length, and the positions of the orbit, internal aperture of the sclerotic ring, external narial aperture, and the anterior tip of the maxilla were marked upon it (Fig. 4). Having obtained a series of straight lines, one for each taxon, they were transferred to a time scale, and the corresponding cranial foci were joined by straight lines (Fig. 5). There are three possible criticisms of this method. First, the resulting graph was constructed from only a few points. Second, when a species was represented by only one individual, bias could result by comparing specimens of different ages. That the graph is constructed from relatively few points reflects the small sample size, but there are some checks that can be made to assess its validity, and these will be discussed later. Discrepancies resulting from allometric growth can largely be dismissed. An extensive investigation into allometric growth in the latipinnate species Ichthyosaurus communis and I. breviceps showed that intracranial growth, for the most part, was isometric (McGowan 1969), and the same also seems to be true for the longipinnate Stenopterygius quadriscissus. Furthermore, the two specimens representing Platyp-

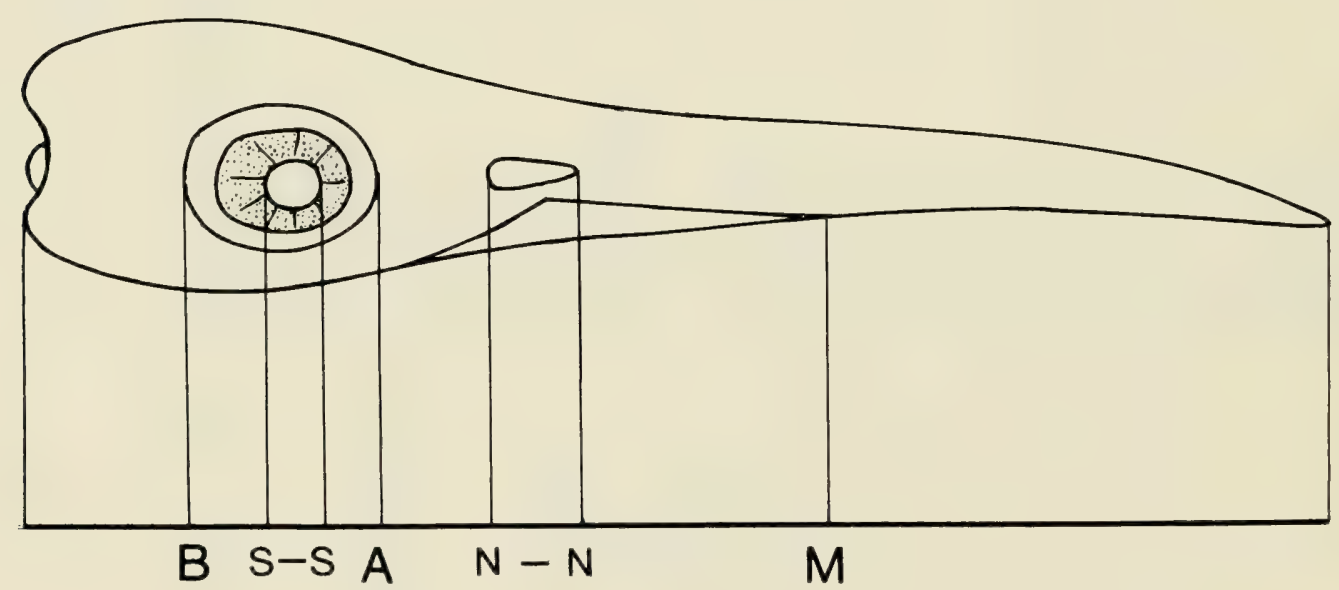

Fig. 4. Generalised ichthyosaur skull showing significant cranial variates converted to linear foci. A - anterior boundary of orbit; B - posterior boundary of orbit; $\mathrm{S}-\mathrm{S}$ - internal diameter of sclerotic ring; N-N - length of external narial aperture; $\mathrm{M}$ - anterior tip of maxilla. 


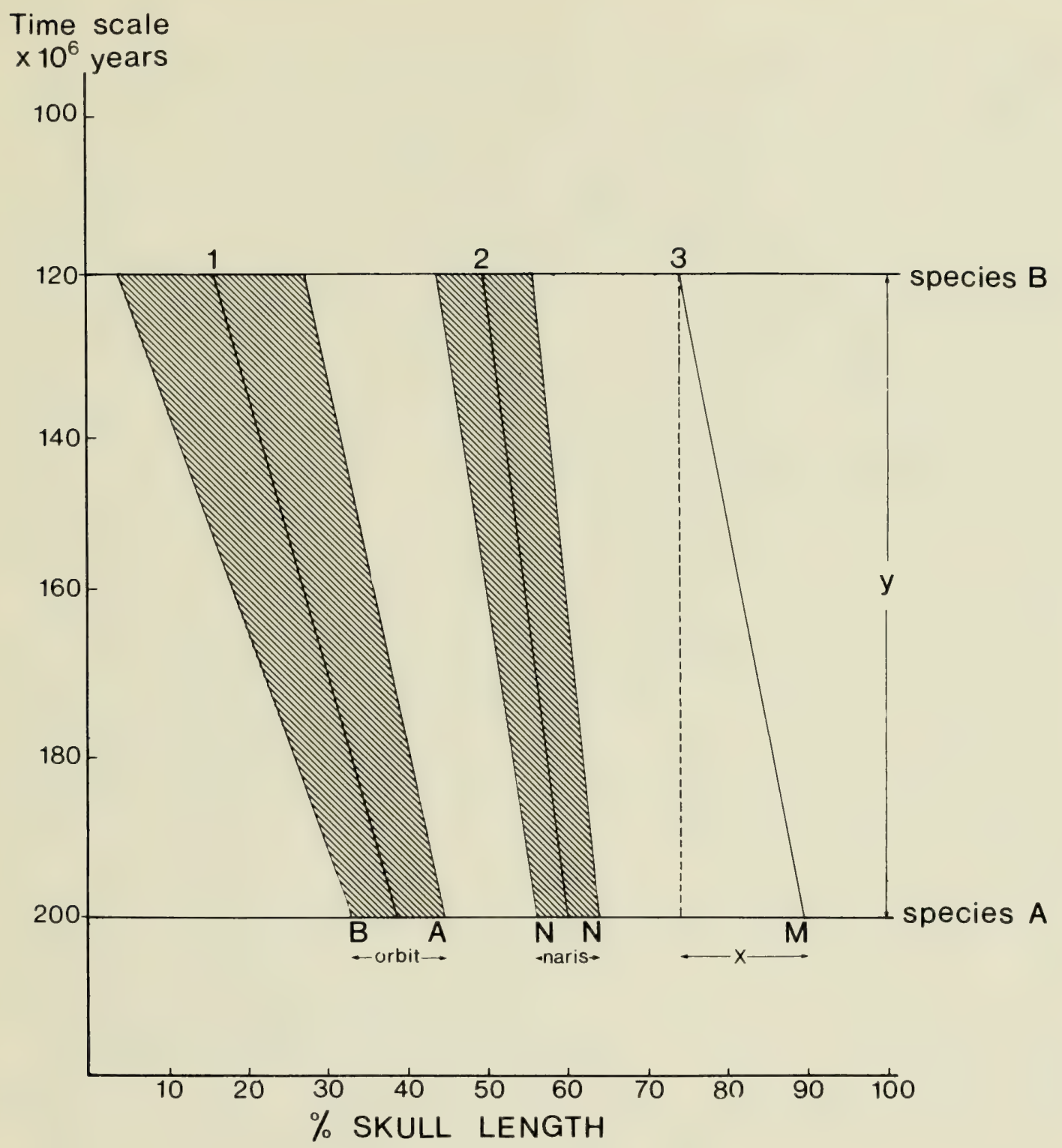

Fig. 5. Straight-line representation of two hypothetical species, A and B, transferred to a time scale. A - anterior boundary of orbit; B - posterior boundary of orbit; N-N - length of external narial aperture; $M$ - anterior tip of maxilla; 1, 2 and 3 - graphs obtained by joining the foci representing respectively the orbital centre, narial centre and the anterior tip of the maxilla. Gradient of graph 3 is $y / x$.

terygius australis and $P$. americanus and the two representing Cymbospondylus petrinus are all obviously mature specimens. A third, more subtle criticism of this technique is that with interspecific variation in the size of the adult skull, the observed changes in orbital and narial sizes could reflect the attainment of optimum organ size in the larger species. Thus, suppose the optimum size of the eye (i.e., that size beyond which an increment does not affect its efficiency) is such as to give an orbital diameter of, say, $10 \mathrm{~cm}$. Clearly, an orbital diameter of $10 \mathrm{~cm}$ in species A (Fig. 6), the skull of which is $100 \mathrm{~cm}$ long, will appear to be relatively smaller than in species B, the adult size of which is $50 \mathrm{~cm}$. If species $\mathbf{A}$ were descended from species $B$, it could be understood that the eye became reduced during evolution, an erroneous conclusion. This problem can be overcome by making comparisons with other species of similar adult skull size and will be discussed later. 


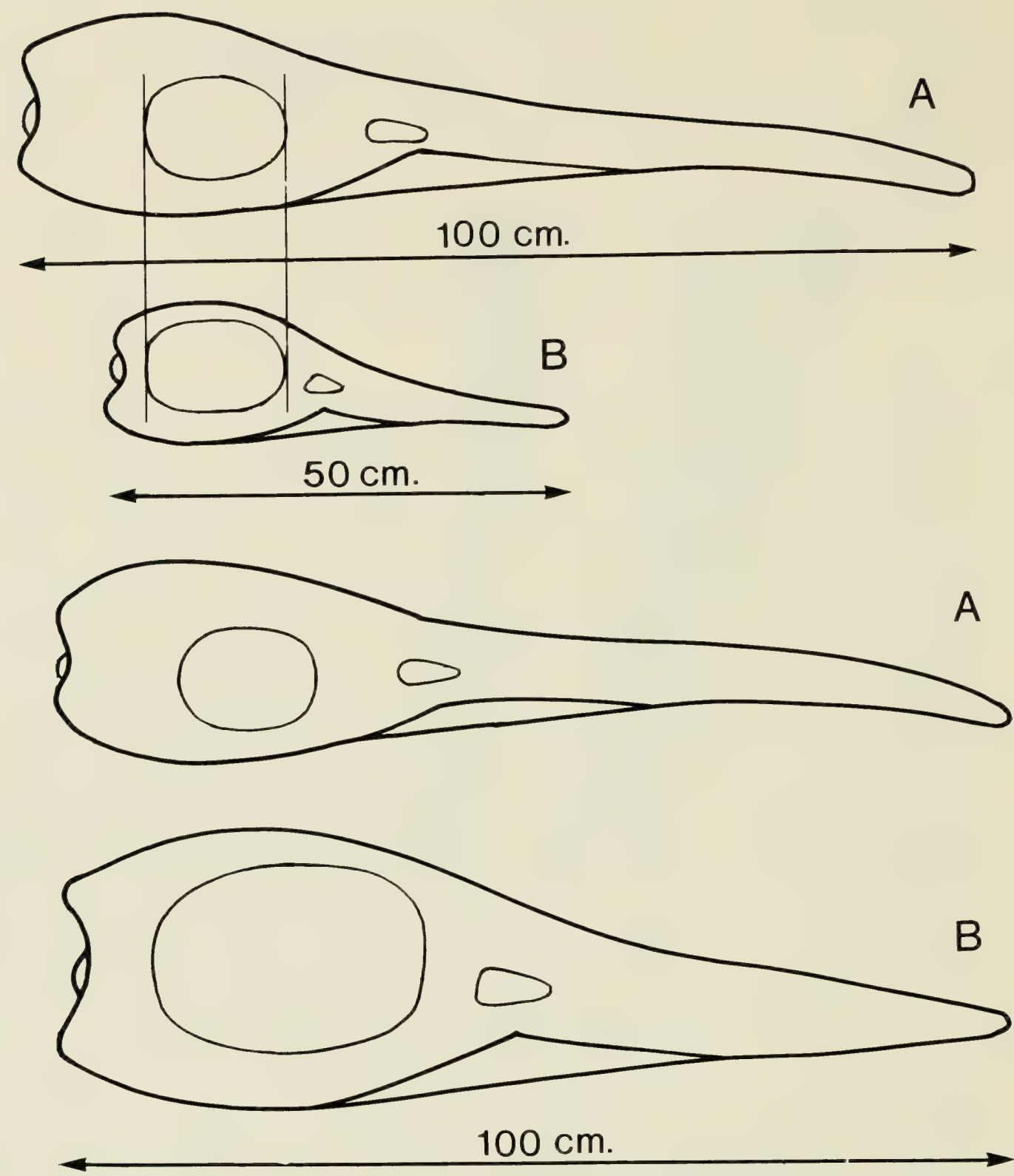

Fig. 6. Comparison of skulls of generalised ichthyosaurs drawn to same scale (upper pair) and to same size (lower pair).

Certain trends occurred during the evolutionary history of the skull that are immediately apparent from the graphic method outlined above. These trends are discussed below, but it is appropriate to define here some of the terms used and to describe how the rates of these changes can be quantified. The orbit and external nares tended to become more posterior in position, resulting in a reduction of the post-orbital portion of the skull. Accompanying these trends was a reduction in relative size of the maxilla, manifest in a posteriorward retreat of the anterior tip of the maxilla. These three trends are referred to in the text as orbital recession, narial recession, and maxillary recession. Changes also occurred in the relative diameter of the orbit, internal diameter of the sclerotic ring, and in the length of the external narial aperture. 
The rates of orbital recession, narial recession and maxillary recession between two given geological horizons were measured graphically (Fig. 5, see also Figs. 13 and 14). Lines were drawn connecting points representing the centres of the orbit, the centres of the external nares, and the anterior tips of the maxillae (Fig. 5, nos. 1 - 3). Gradients of these three lines were then measured between the various geological horizons. The gradient of a given line between two given horizons has the units of time/per cent recession. Thus, the reciprocal of the gradient has the units of per cent recession/unit time and is therefore a measure of the actual rate of recession of the character in question. For example, in Fig. 5 the gradient of line 3 is $y / x$, so that the rate of maxillary recession, the reciprocal of this gradient, is given by $\mathrm{x} / \mathrm{y}$ and has the units of per cent recession per $10^{6}$ years.

The rates of change in the diameter of the orbit, internal diameter of the sclerotic ring, and length of the external narial aperture between two given horizons are obtained directly. Thus, to compare the rate of change in the diameter of the orbit between, say, the Middle Triassic and Lowermost Jurassic, the difference between orbital diameters of ichthyosaurs at these two horizons is taken and divided by the time interval between them (about $30 \times 10^{6}$ years). The units of the rate of change are per cent change $/ 10^{6}$ years, but, since changes in size of cranial characters are more rapid than recession rates, it was more convenient to express size changes in units of $4 \times 10^{6}$ years, the approximate separation in time between Lower and Upper Liassic.

A graphic method similar to that used in tracing the changes in the skull was used to investigate the evolutionary changes occurring in body shape throughout geological time. Because growth of the skull relative to the body is not isometric (see McGowan, 1969) and because there is a tendency for the angle of the tail bend to increase with size, it is important to select adults for this treatment. First, all relevant data for the shape of the body were collected for each taxon. A straight line representation of the body of each taxon was then produced (Fig. 7), the trunk made equal to unit length. Representations thus produced were then transferred to a time scale (see Fig. 17).

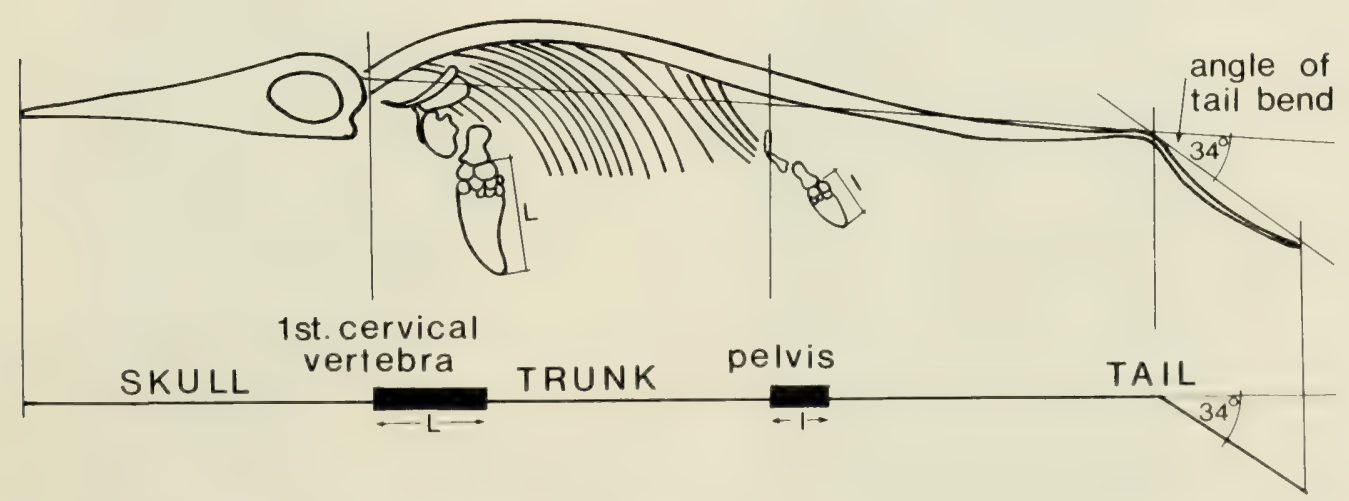

Fig. 7. Conversion of significant variates of the ichthyosaurian body to linear foci. $\mathbf{L}-$ length of fore fin; 1 - length of hind fin. The lengths of the fins are shown in the diagram by the lengths of the black bars. 
When a given evolutionary trend, e.g., orbital recession, has barely progressed in a given taxon, that taxon is said to be primitive with respect to that particular character. When the trend has progressed considerably the taxon is said to be advanced with respect to that particular character.

Abbreviations for institutions referred to in the text are as follows: BMNH, British Museum (Natural History), London; SMc, Sedgwick Museum, University of Cambridge; UCMP, Museum of Paleontology, University of California, Berkeley; UW, University of Wyoming, Laramie; oum, Oxford University Museum; QMA, Queensland Museum, Australia.

Fig. 8. Comparison of Cymbospondylus and Platypterygius. A. Cymbospondylus petrinus UCMP 9913, Middle Triassic, Nevada, U.S.; B. Platypterygius americanus Uw 2421, Lower Cretaceous/Upper Cretaceous boundary, Wyoming, U.S.; C. $\boldsymbol{P}$. americanus UW 2421, right fore fin, ventral view; D. P. australis QMA F3348 (and F3388), right fore fin, dorsal view, Lower Cretaceous, Queensland, Australia. Scale $=10 \mathrm{~cm}$. 


\section{The Genus Platypterygius (Fig. 8)}

The systematics of Platypterygius and the structure of the fore fin were discussed in detail elsewhere (McGowan, in press, Contr. Geol.). For a detailed description of the skull, the reader is referred to Romer (1968). Additional information may be found in Nace $(1939,1941)$ and Broili (1907). Further description of Platypterygius here would be superfluous, but it would be useful to compare it with certain other longipinnate genera.

A
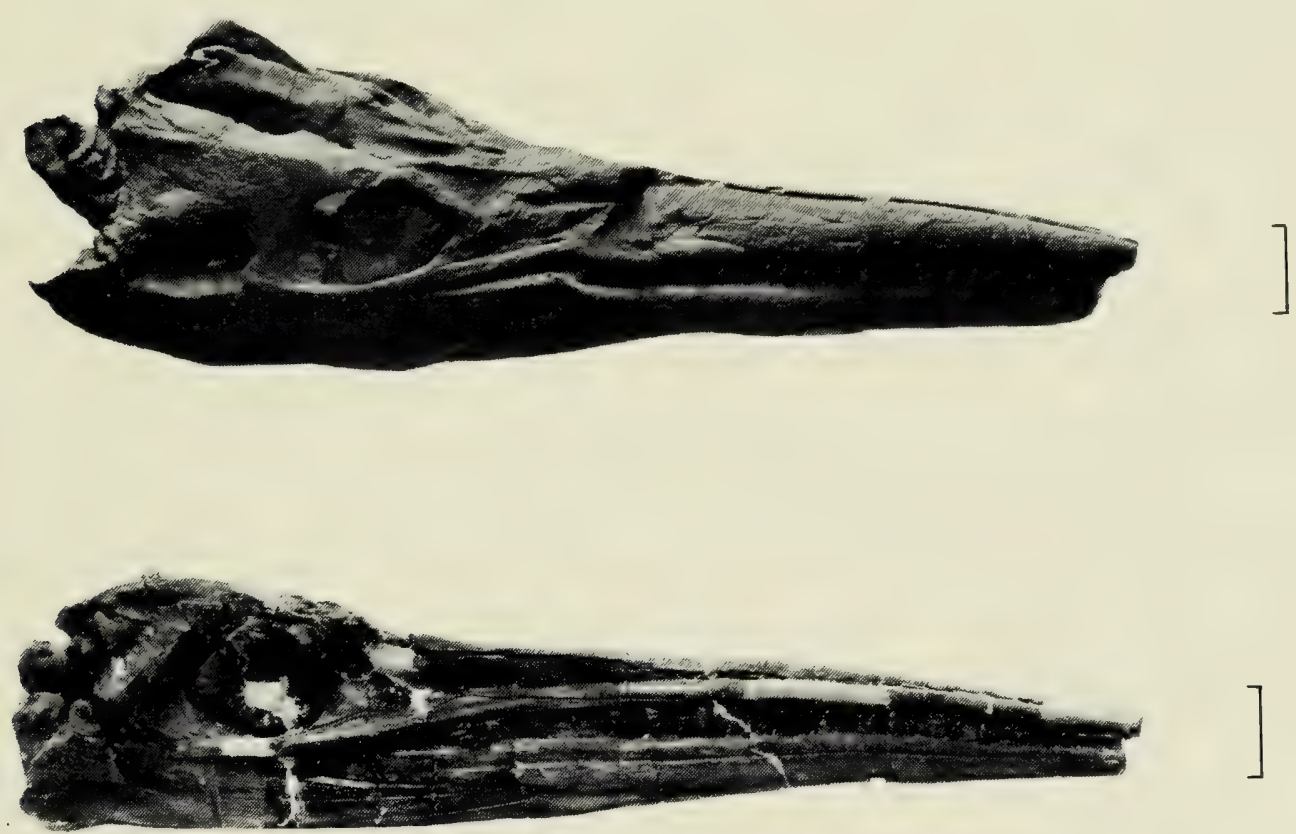

B
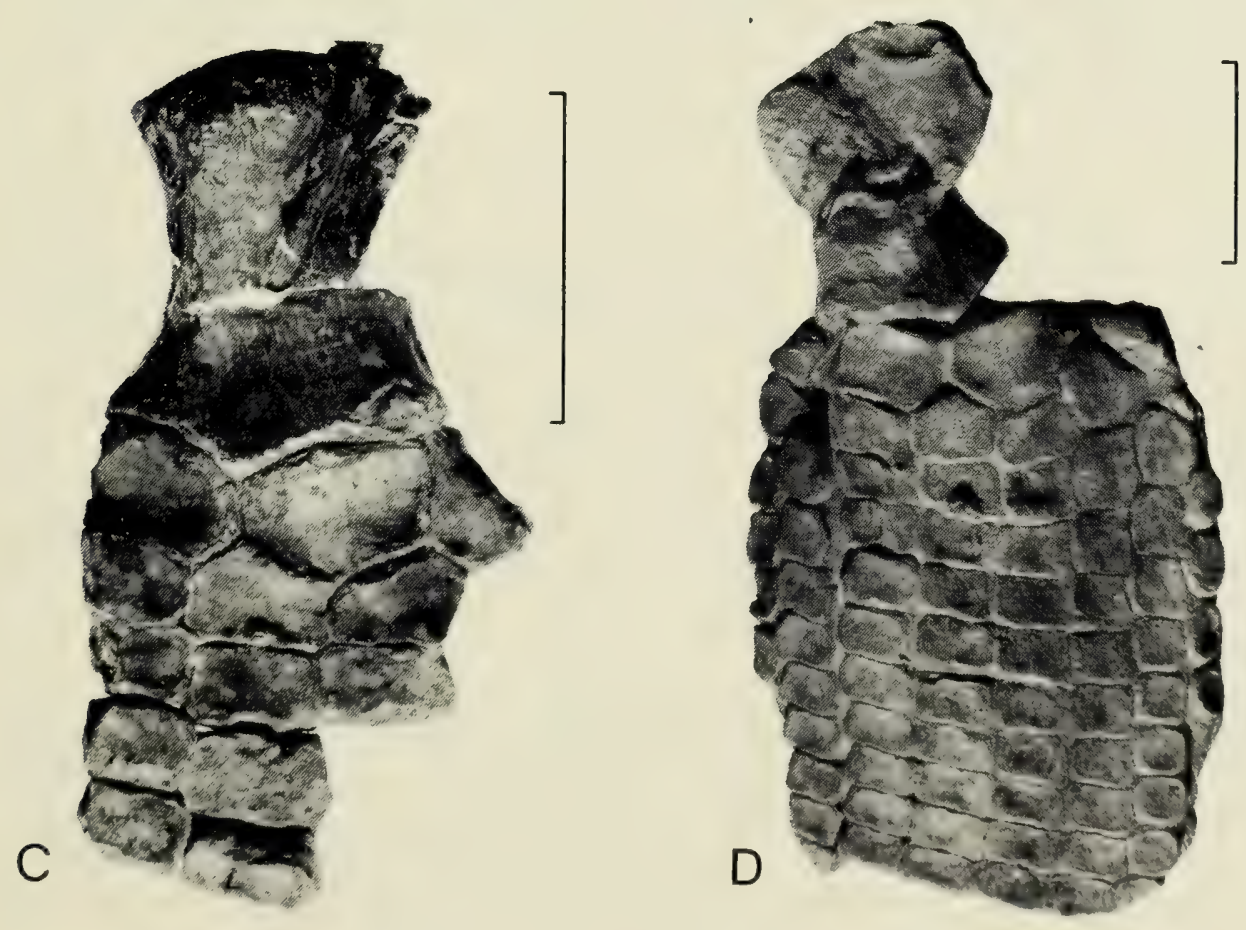


\section{Comparison of the skull of Platypterygius with those of Cymbospondylus, Proteosaurus, and Stenopterygius (Fig. 9)}

The skull of Platypterygius is more slender than that of Cymbospondylus and has a lower crown. The orbit is smaller in Platypterygius, but the internal diameter of the sclerotic ring is about the same in both genera. The orbit is set more posteriorly in Platypterygius, so that the snout is correspondingly longer and the post-orbital segment shorter. The maxilla, robust in Cymbospondylus, is slender in Platypterygius and does not extend as far anteriorly. The size of the external narial aperture is similar in both genera, and teeth are sparse.

Compared with the Lower Liassic genus Proteosaurus, the skull of Platypterygius is more slender and has a much narrower lower jaw. The orbit is smaller in Platypterygius and placed more posteriorly, but the internal diameter of the sclerotic ring is comparable in the two. The narial aperture of Platypterygius is smaller, and the maxilla is more slender and does not extend so far forward as in Proteosaurus.

When Platypterygius is compared with the Upper Liassic genus Stenopterygius, the contrast is striking. Although both skulls are slender, with tenuous upper and lower jaws, Platypterygius has a cranial depth and orbital diameter only half that of Stenopterygius. The internal diameter of the sclerotic ring is also considerably smaller in Platypterygius, as is the length of the external narial aperture. Although the maxilla is slender in both genera, it extends farther forward in Platypterygius.

In short, Platypterygius has a slender, low-crowned skull and an orbit that is slightly smaller even than that of Cymbospondylus. The position of the orbit is more posterior than in any other genus, except Stenopterygius (in which orbital position is similar); and the maxilla is slender and extends more anteriorly than in Stenopterygius but not as far forward as in either Cymbospondylus or Proteosaurus.

\section{Comparison of fore fins of Platypterygius and Stenopterygius} (Fig. 10)

The fore fins of these two genera, although superficially dissimilar, have several features in common. The fins of both taxa possess a distal carpal series of three elements (numbers $1-3$ in Fig. 10), three primary digits, and two post-axial accessory digits. Platypterygius, however, possesses three pre-axial accessory digits. Furthermore, in Platypterygius the distal phalanges are not much smaller than the proximal ones and appear to remain in contact with one another. The fore fin of Platypterygius, therefore, is much broader and more robust than in Stenopterygius. Although not apparent in Fig. 10, the humerus of Platypterygius has prominent dorsal and ventral trochanters (for the insertion of the extensor and flexor muscles) that are not found in Stenopterygius (see Fig. 8). 

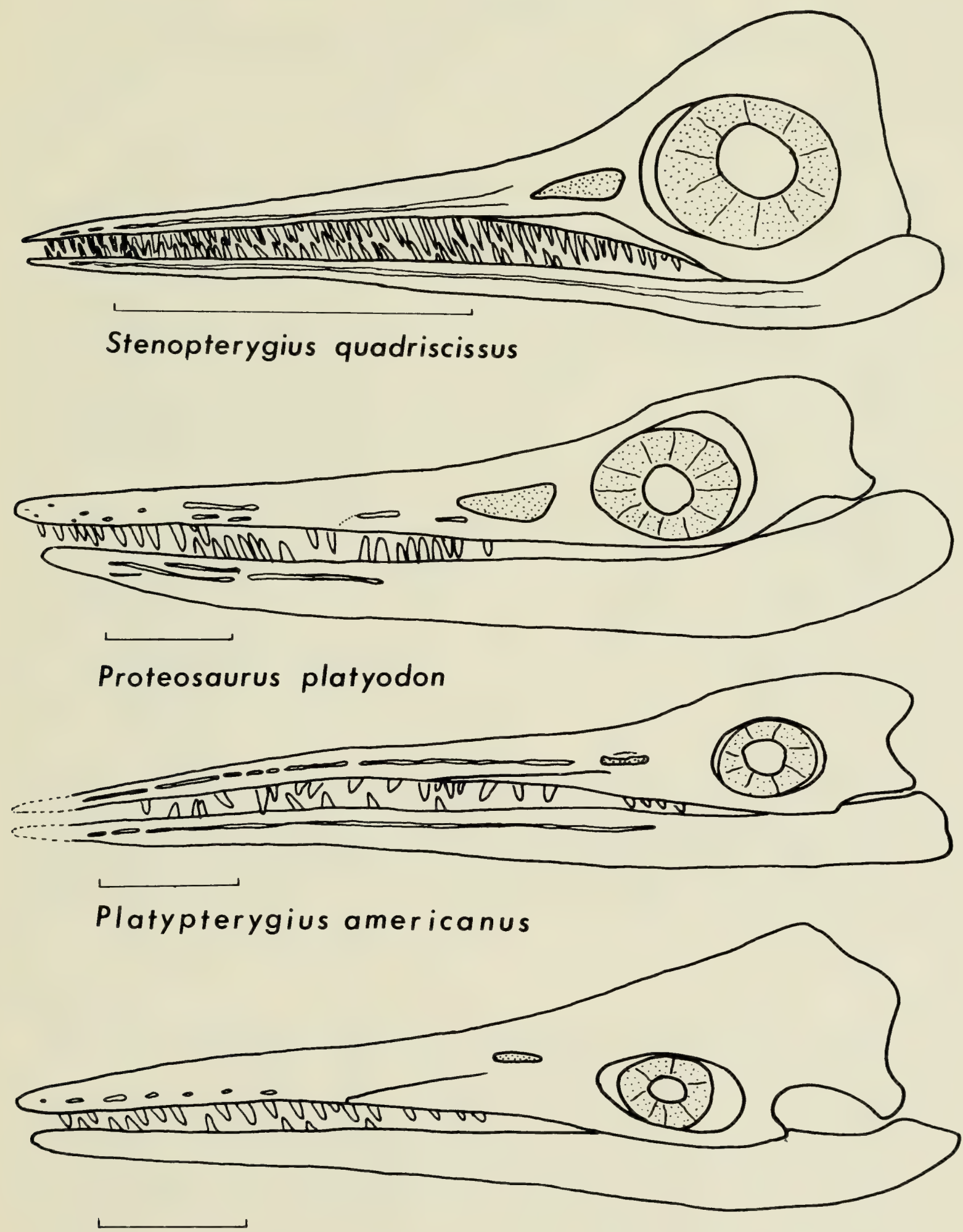

\section{Cymbospondylus petrinus}

Fig. 9. Comparison of the skulls of longipinnate ichthyosaurs. Stenopterygius quadriscissus roм 3180, Upper Liassic (Lower Toarcian) Germany; Proteosaurus platyodon BMNH R1158, Lower Liassic (Hettangian-Sinemurian), England; Platypterygius americanus Uw 2421, Lower Cretaceous (Upper Albian), Wyoming, U.S.; Cymbospondylus petrinus UCMP 9913, Middle Triassic, Nevada, U.S. Scale $=20$ $\mathrm{cm}$. 

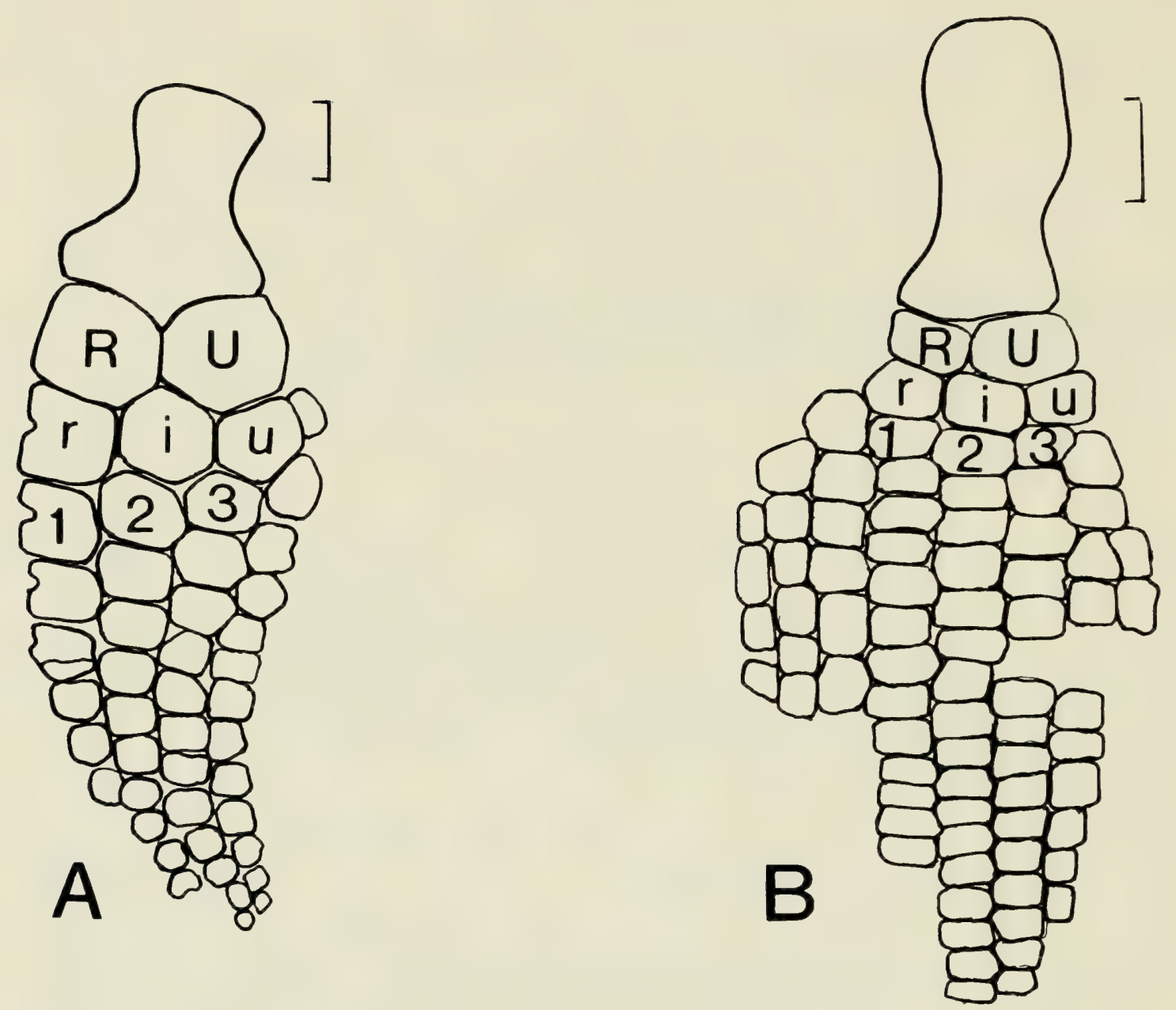

Fig. 10. Comparison of the fore fins of Stenopterygius and Platypterygius. A. Stenopterygius quadriscissus BMNH R4086, right fore fin, dorsal view (figure has been laterally inverted and therefore appears as a left fin in dorsal view); B. Platypetrygius platydactylus left fore fin, dorsal view (after Broili, 1907, fig. 13). Scale $=4 \mathrm{~cm}$.

\section{Comparison of body proportions of Platypterygius with those of Proteosaurus and Stenopterygius (Fig. 11)}

Difficulties arise when body proportions are compared because of the problem of differential growth, but, provided only adult individuals are selected, bias is at least reduced. Choice could not be exercised in the selection of Platypterygius, however, as only one complete specimen has been described ( $P$. platydactylus Broili 1907, which was destroyed during World War II); but from its large size, it was probably adult. In Proteosaurus and Stenopterygius it was possible to select the largest individuals, which were obviously adult. Proteosaurus and Stenopterygius have similar body proportions but differ from Platypterygius. The head of Platypterygius is considerably larger, the angle of the tail bend greater, and the postflexural portion of the tail is considerably shorter than in the other two genera. Fore fins are proportionally the same size in all three genera but are somewhat wider and more rounded in Platypterygius. The length of the body anterior to the tail bend is longer in Platypterygius. 


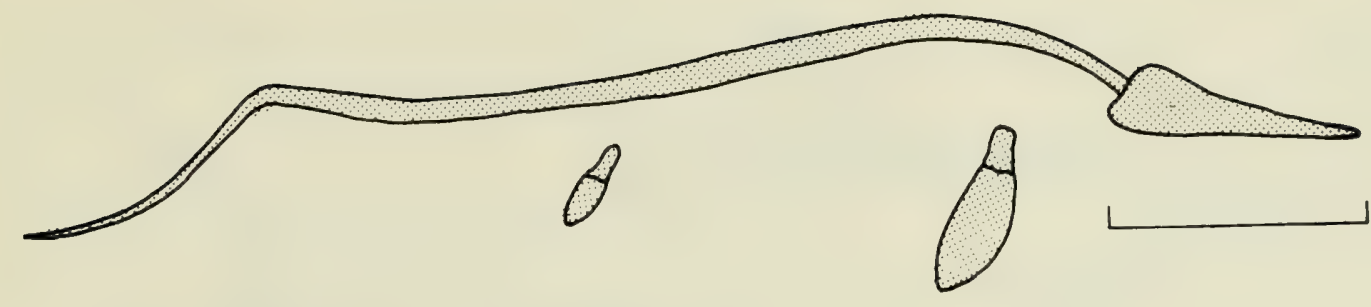

Stenopterygius quadriscissus

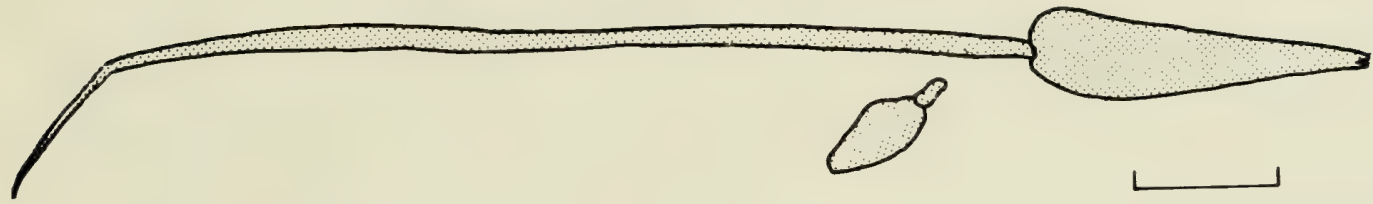

Platypterygius platydactylus

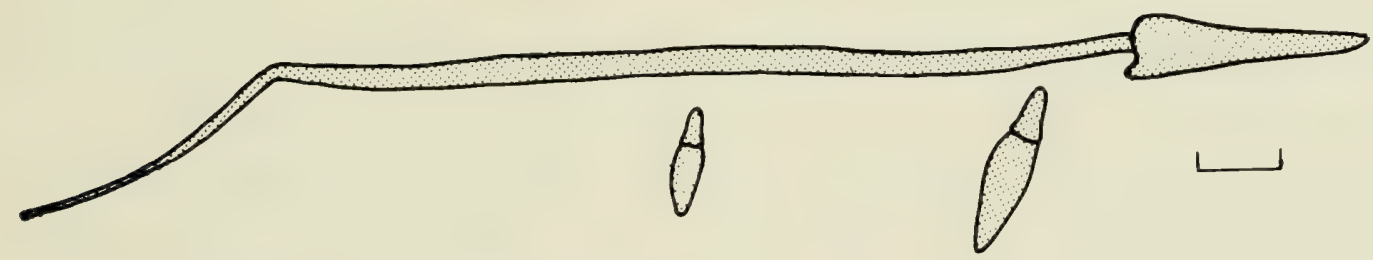

Proteosaurus platyodon

Fig. 11. Diagrammatic comparison of body proportions in Stenopterygius quadriscissus, adapted from Hauff (1953, pl. 9b); Platypterygius platydactylus, adapted from Broili (1907, pl. 12); and Proteosaurus platyodon, BMNH 2003. Scale $=50 \mathrm{~cm}$.

\section{Summary}

From all comparisons, Platypterygius emerges as a mosaic of primitive and advanced characters. In orbital and narial recession Platypterygius is more advanced than Cymbospondylus or Proteosaurus and is comparble to Stenopterygius. But in the size of the orbit, Platypterygius is as primitive as Cymbospondylus, whereas in the reduction of the maxilla it is intermediate between Cymbospondylus and Stenopterygius. Although the extreme angle of the tail bend in Platypterygius is not without precedence (the angle of the bend in Eurhinosaurus is slightly greater), the shortness of the post-flexural section of the tail is probably unprecedented. It is the unique structure of the fore fin, however, that distinguished Platypterygius from all other ichthyosaurs. A reconstruction of Platypterygius platydactylus is given in Fig. 12 and compared with that of Stenopterygius quadriscissus. 


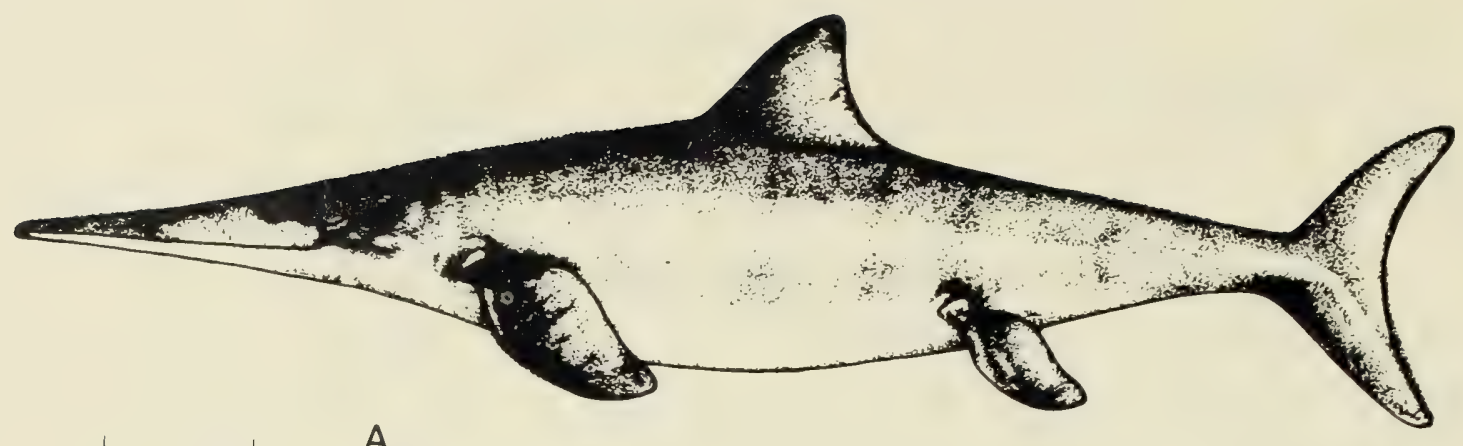

A

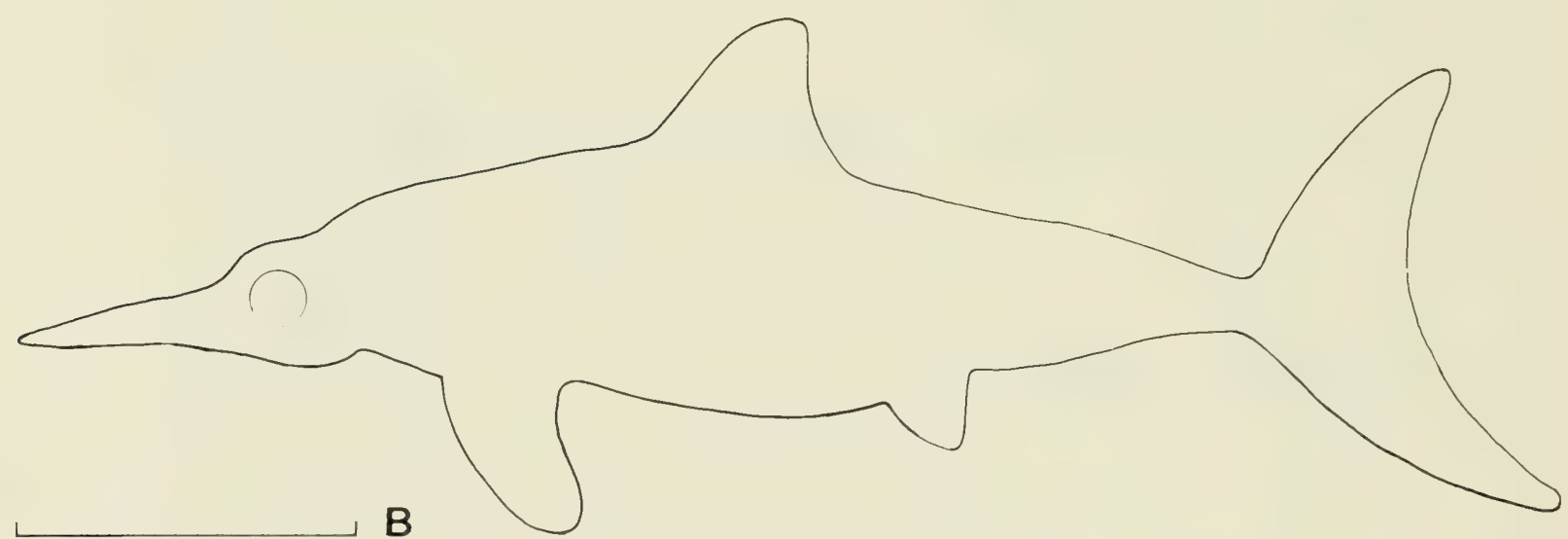

Fig. 12. Comparison of body form in Lower Jurassic and Cretaceous longipinnate ichthyosaurs. A. Reconstruction of Platypterygius, based upon the type specimen of $P$. platydactylus (Broili, 1907, pl. 12), the tvpe specimen of $P$. hercynicus (Kuhn, 1946, pl. 3), P. americanus (UW 2421) and P. australis (QMA F3348); B. body outline of Stenopterygius quadriscissus (adapted from Hauff, 1953, pl. 7a). Scale $=50 \mathrm{~cm}$.

\section{Discussion}

Platypterygius, a moderately large ichthyosaur that attained a maximum length of about seven metres, was larger than most Liassic longipinnates but smaller than the Middle Triassic longipinnate Cymbospondylus. The angle of the tail bend was large, and the post-flexural portion of the tail short. As the ichthyosaurian tail was externally symmetrical, its overall size was proportional to the length of the post-flexural segment. The tail of Platypterygius was thus relatively small when compared with that of a Liassic longipinnate (Fig. 12). While swimming, the forward propulsive thrust of the ichthyosaurian tail was accompanied by a downward thrust produced by the epicaudal lobe. The relative magnitude of the epicaudal downward thrust was inversely proportional to the angle of the tail bend, whereas the forward thrust produced by the entire tail was a direct function of its size (McGowan, in preparation). As the tail of Platypterygius was small and steeply angled, it must have produced relatively smaller downward and forward propulsive thrusts than the tail of Stenopterygius. The dorsal and ventral trochanters of the humerus of Platyptery- 
gius were enormously developed and indicative of an extensive musculature. The femur similarly possessed large dorsal and ventral trochanters, and it seems clear that the fore fins (probably also the hind fins) contributed to the forward propulsive thrust, thus augmenting the power output of the tail.

Functionally there are two types of fore fins, a broad-based structure with a low aspect ratio used as a hydroplane, and a narrow-based structure with a high aspect ratio probably used mainly for sculling (McGowan, in press, Cont. Geol.). Although the hydroplane, by far the most common, is found in longipinnates and latipinnates, the narrowbased fin is found only in longipinnates (with the possible exception of Ophthalmosaurus) and is uncommon. Platypterygius had a fairly low aspect ratio fin, and although it may be paradoxical that a low aspect ratio structure should be used for sculling, parallels exist in cetaceans and in some aquatic chelonians. Thus Inia geoffrensis, the Amazon dolphin, has a broad but narrow-based fin that is frequently used for sculling (McGowan, personal observation). An extensive attachment area for the muscles of the fore fin must have been present in Platypterygius, but the ichthyosaurian pectoral girdle is not extensively developed, especially when compared with plesiosaurs, which used their paddles almost exclusively for producing thrust (see Tarlo, 1958). But there is evidence that the pectoral girdle was a fairly stout structure and that the scapula was large and heavy (Nace, 1939, 1941; McGowan, in press, Cont. Geol.). Moreover, in some vertebrates certain flexor muscles originate outside the pectoral girdle, and the ribs could have provided an extensive attachment area for these muscles in Platypterygius.

In conclusion, Platypterygius used its fore fins mainly for propulsion, augmenting the thrust of the tail. Even so, the use of the fins as hydroplanes is not precluded, and they probably did have a dual role. The fore fin is less efficient at producing thrust than the tail (every other stroke of a fin is a recovery stroke, whereas every stroke of a tail is a power stroke), and as Platypterygius probably obtained much of its propulsive thrust from its fore fins, swimming efficiency may have been inferior to that of its Liassic predecessors.

In Platypterygius the orbit and internal diameter of the sclerotic ring are both small when compared with Liassic longipinnates, possibly indicative of an eye that functioned under high light intensities. Perhaps Platypterygius spent much of its time at, or near the surface, and did not dive deeply in search of food. As in the Liassic longipinnates, the long snout and sharp teeth suggest a diet of fish and cephalopods. 


\section{The Evolution of Longipinnate Ichthyosaurs}

The evolutionary sequence of the longipinnates was determined by examining and comparing the most adequately known species throughout geological time. Unfortunately, the sequence had to be constructed from only six species, representing but four geological horizons: Cymbospondylus petrinus, Middle Triassic, Nevada; Proteosaurus platyodon, Lower Liassic, England; Proteosaurus sp.* (a new species not yet described), Lower Liassic, England; Stenopterygius quadriscissus, Upper Liassic, Germany; Platypterygius australis, uppermost Lower Cretaceous, Queensland, Australia; and Platypterygius americanus, boundary between Lower and Upper Cretaceous, Wyoming, U.S. Data extracted from the material were used to investigate the evolutionary changes taking place in the skull, body proportions, and the fore fin.

\section{Evolution of the Longipinnate Skull}

Results of the graphic treatment (outlined above in Materials and Methods) are shown in Figs. 13 and 14. When the method was discussed, it was

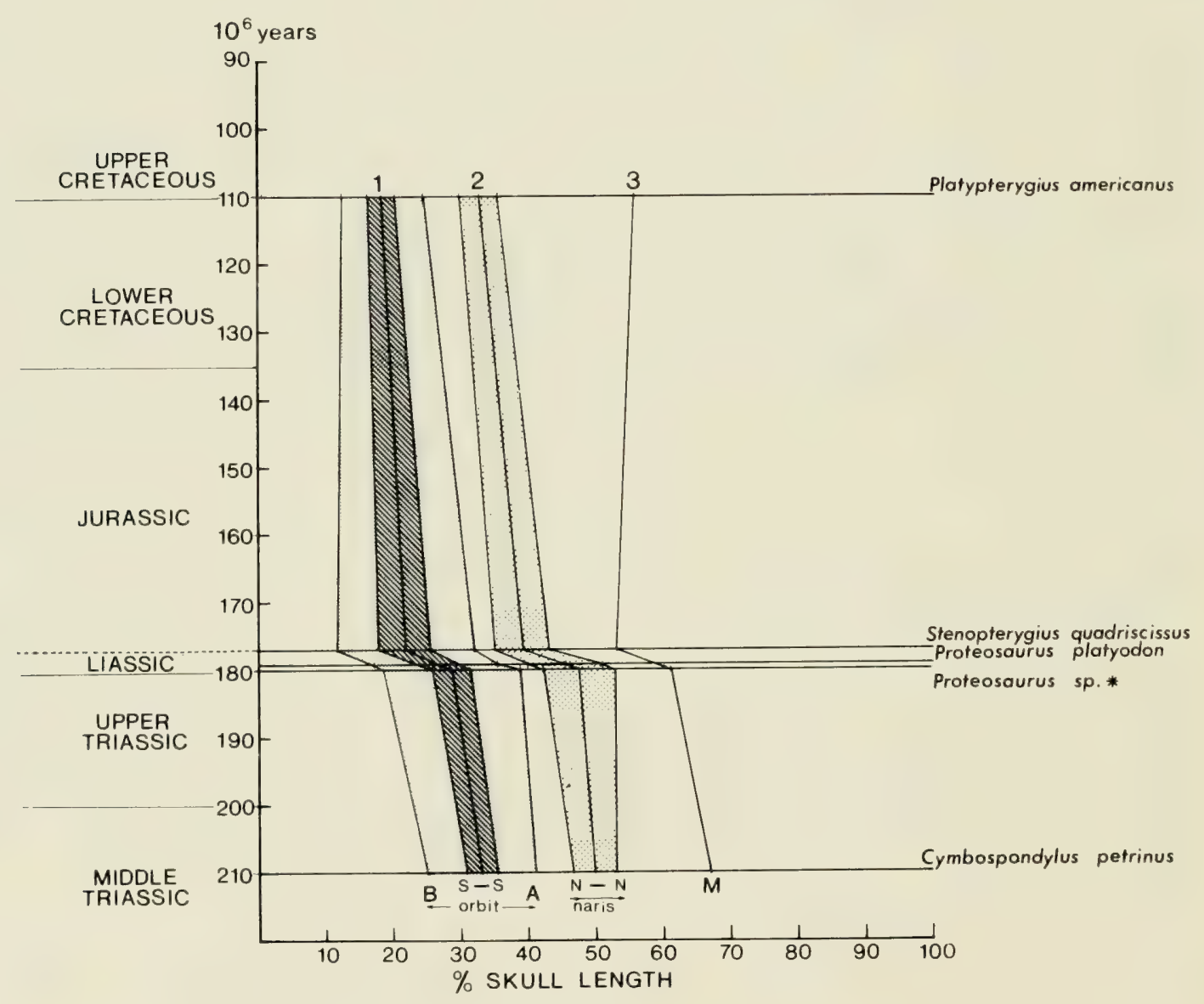

Fig. 13. Changes in significant cranial characters in the evolution of species of longipinnate ichthyosaurs. A - anterior boundary of orbit; B - posterior boundary of orbit; S-S - internal diameter of sclerotic ring; N-N - length of external narial aperture; $M-$ anterior tip of maxilla; 1,2 and 3 - graphs obtained by joining the foci representing respectively the orbital centre, narial centre, and the anterior tip of the maxilla. 
shown that problems could arise out of variations in adult skull size. The problem arises here because Platypterygius americanus had an adult skull more than twice as long as that of Stenopterygius quadriscissus. Was there an actual reduction in the size of the orbit, sclerotic, and narial apertures from the Liassic to the Cretaceous, or merely a proportional reduction, which would be less meaningful functionally? There was in fact a reduction in size as well as in proportion, as is demonstrated by comparing $P$. americanus with species of Stenopterygius from the Upper Liassic of comparable adult skull size. Thus, if $S$. disinteger (Hauff, 1953, pl. 18a) and $S$. acutirostris (?) (Hauff, 1953, pl. 19a), with skull lengths of $97 \mathrm{~cm}$ and $153 \mathrm{~cm}$, respectively, are compared with Platypterygius americanus (Uw 2421), skull length $122 \mathrm{~cm}$, and if skulls of all three are reduced to unit size, it is seen that the orbital, sclerotic, and narial apertures of the two Upper Liassic taxa are significantly larger. An actual decrease in the finite sizes of the orbital, sclerotic, and narial apertures thus occurred in ichthyosaurs from Liassic to Cretaceous times.

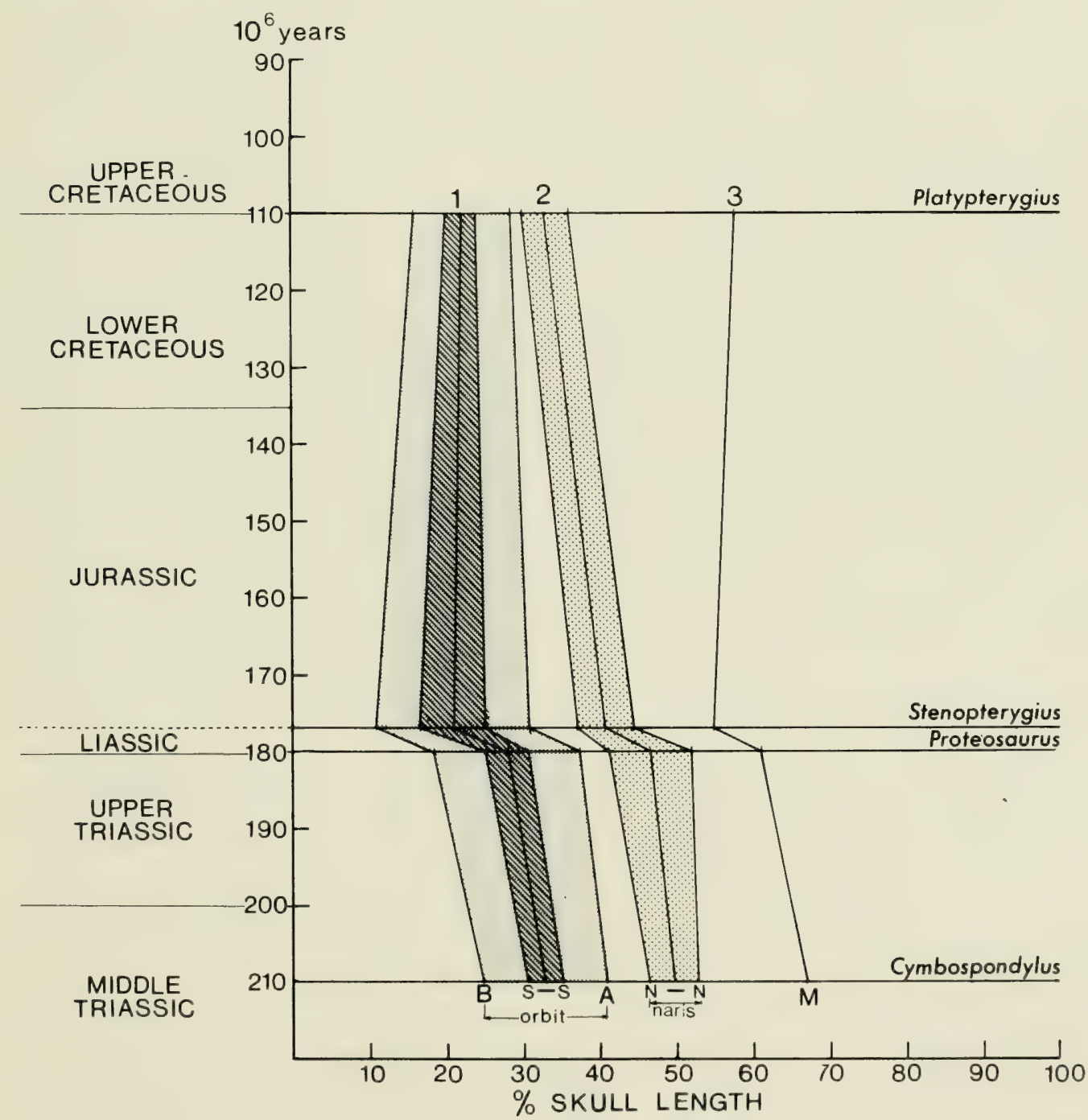

Fig. 14. Changes in significant cranial characters in the evolution of genera of longipinnate ichthyosaurs. A - anterior boundary of orbit; B - posterior boundary of orbit; S-S - internal diameter of sclerotic ring; N-N - length of external narial aperture; $\mathbf{M}$ - anterior tip of maxilla; 1, 2 and 3 - graphs obtained by joining foci representing respectively the orbital centre, narial centre, and anterior tip of the maxilla. 
Leaving aside the well-marked hiatus at the Lower Jurassic, shortly to be discussed, several generalisations may be made from data given in Figs. 13 and 14. Throughout the evolution of the ichthyosaurs, there was a wellmarked tendency for the orbit and external narial aperture to move posteriorly. Also migrating posteriorly was the anterior boundary of the maxilla, resulting from a reduction in the length of the maxilla. Accompanying these changes in relative position of the orbit and external naris were changes in their relative sizes.

From the Middle Triassic to the Lower Liassic (early Jurassic), the diameter of the orbit increased by about $25 \%$, with a corresponding increase of about $20 \%$ in the internal diameter of the sclerotic ring. From the Lower Liassic to the Upper Liassic the diameter of the orbit was constant, but the internal diameter of the sclerotic ring increased by about $40 \%$. From the Upper Liassic to the Cretaceous, the orbital and internal sclerotic diameters decreased by about $40 \%$, both becoming quite small. The size of the external narial aperture increased by more than $60 \%$ from the Middle Triassic to the Lower Liassic, but from the Lower Liassic to the Cretaceous, there was an almost steady decrease of about $30 \%$.

\section{POSSIBLE SIGNIFICANCE OF CRANIAL CHANGES}

The posterior migration of the eye and external narial aperture during the evolutionary history of the ichthyosaurs increased the relative length of the snout. As the snout is the dentulous portion of the skull, the increase in length may have been correlated with increasing the food-gathering capacity of the head. That the increase in snout length was correlated with improving the streamlining of the body is also possible. As the eyes and olfactory organs migrated, the optic and olfactory lobes of the brain also moved posteriorly; consequently, the brain case became relatively shorter, but the significance of this is not known. The reduction in size of the maxilla does not appear to have had any discernable functional significance. The margin of the upper jaw was formed from the premaxilla and maxilla, but the contribution of the latter was minor. As ichthyosaurs evolved, the maxilla became progressively reduced, a tendency reflected in the posterior shift of the anterior tip of the maxilla (Figs. 13, 14).

Changes in orbital and internal sclerotic ring diameters are treated together because of their close relationship. Before discussing the significance of these changes, however, the respective functions of these structures need consideration. The orbit is the receptacle of the eye and is directly proportional to the size of the eye. But the size of the eye is not proportional to the size of the pupil, and it is the size of the pupil that gives information on how the eye was used. Direct evidence of pupil size can be obtained from the sclerotic apparatus. Underwood (1970) discussed the significance of the presence of the sclerotic sulcus in supporting the cornea in those recent reptiles that use their eyes above and beneath the surface of the water, and McGowan (in press, Bull. Br. Mus.) demonstrated that such a structure was absent from the sclerotic ring of Liassic latipinnates. A sulcus was also absent from the Liassic longipinnates that I examined and from the longipinnates Cymbospondylus petrinus (UCMP 
9913) and Platypterygius americanus (UW 2421). I conclude that a sulcus was probably absent from all ichthyosaurs, and that they used their eyes exclusively for underwater vision.

Except during the Liassic, changes in the diameters of the orbital and sclerotic apertures were of the same magnitude. During the Liassic the orbital diameter remained constant, whereas the size of the sclerotic aperture increased greatly. Consequently the size of the pupil increased without any increment in the size of the eye. Perhaps Upper Liassic longipinnates inhabited deeper waters where light intensities were lower, or perhaps the turbidity of the sea was greater than it had been previously. From the late Liassic onward, orbital and sclerotic apertures gradually decreased in size at approximately equal rates. The size of the eye and of the pupil were thus decreasing, again possibly indicating changing habits or environments. Certain features of the post-cranial skeleton of Platypterygius, discussed above, suggest that the animal did not dive deeply, which could account for the relative small size of the sclerotic aperture.

The external narial aperture has two functions, respiration and olfaction. McGowan (in press, Bull. Br. Mus.) suggested that the function of the olfactory organ of Liassic latipinnates may have been to determine the quality of the water rather than that of the inspired air, and that water was probably continuously monitored while the animal was submerged. I also tentatively suggested that the median-dorsal internasal foramen, a structure seen in a number of latipinnate ichthyosaur skulls from the Liassic, might have functioned in respiration. Moreover, I recently identified the same structure in some Liassic longipinnates (Proteosaurus platyodon ROM 7972, BMNH R 1155, BMNH R 215) and it could well be that this foramen was consistently present, at least in Liassic ichthyosaurus. During the interval between the early Triassic and the beginning of the Jurassic, the size of the narial aperture increased, and was followed by a rapid reduction in the early part of the Jurassic, a trend that continued, though at a reduced rate, till late Cretaceous times (Figs. 13,14). What was the functional significance of these changes? From the standpoint of respiration it is reasonable to assume that there was a certain minimum size of the narial aperture for normal respiratory exchange. The narial aperture of Cymbospondylus was smaller than in any pre-Cretaceous ichthyosaur but must have been adequate for respiratory exchange. As Cymbospondylus was probably the largest ichthyosaur in body mass, the increase in size of the narial aperture after the Middle Triassic may not have been correlated with respiratory function (not unless post-Triassic longipinnate ichthyosaurs were considerably more active than Cymbospondylus, and required correspondingly larger nares for the increased rate of respiratory exchange). The increment in narial size from the Triassic to the beginning of the Jurassic may therefore have been correlated with increased olfactory acuity rather than with an increased respiratory demand. The inverse relationship between the size of the narial and sclerotic apertures during the Liassic is probably significant. Could the Liassic have been a period of transition from an 
olfactory to a visually-dominated sensory system? That the decrease in narial aperture was correlated with the appearance of the internasal foramen is also possible.

RATES OF CHANGE IN CRANIAL EVOLUTION OF LONGIPINNATE ICHTHYOSAURS Although the fossil record is far from complete, it is possible to obtain some idea of the rates at which evolutionary processes occurred in the longipinnate skull (see Materials and Methods), and results are shown in Figs. 15 and 16. Three generalisations emerge from this study: (1) During a given interval of time, the individual characters of the skull did not change at the same rate. For example, during the interval from the Triassic to the early Liassic the increase in narial length was about twice as fast as the rate of increase in orbital diameter (Fig. 15). (2) The direction of a given change sometimes reversed. Thus, the size of the external naris increased during pre-Liassic times, then decreased (Fig. 15). Similarly, the trend toward an increase in orbital and internal sclerotic diameters was reversed in post-Liassic times. (3) The most rapid rate of change occurred during the Liassic, an interval of some 4 million years, whereas the slowest rate of change occurred during the interval from late Liassic to late Cretaceous, about 65 million years.

Different cranial characters not only evolved at different rates during the geological history of the longipinnates, but a given structure was sometimes acted upon by two different evolutionary forces (Figs. 15,

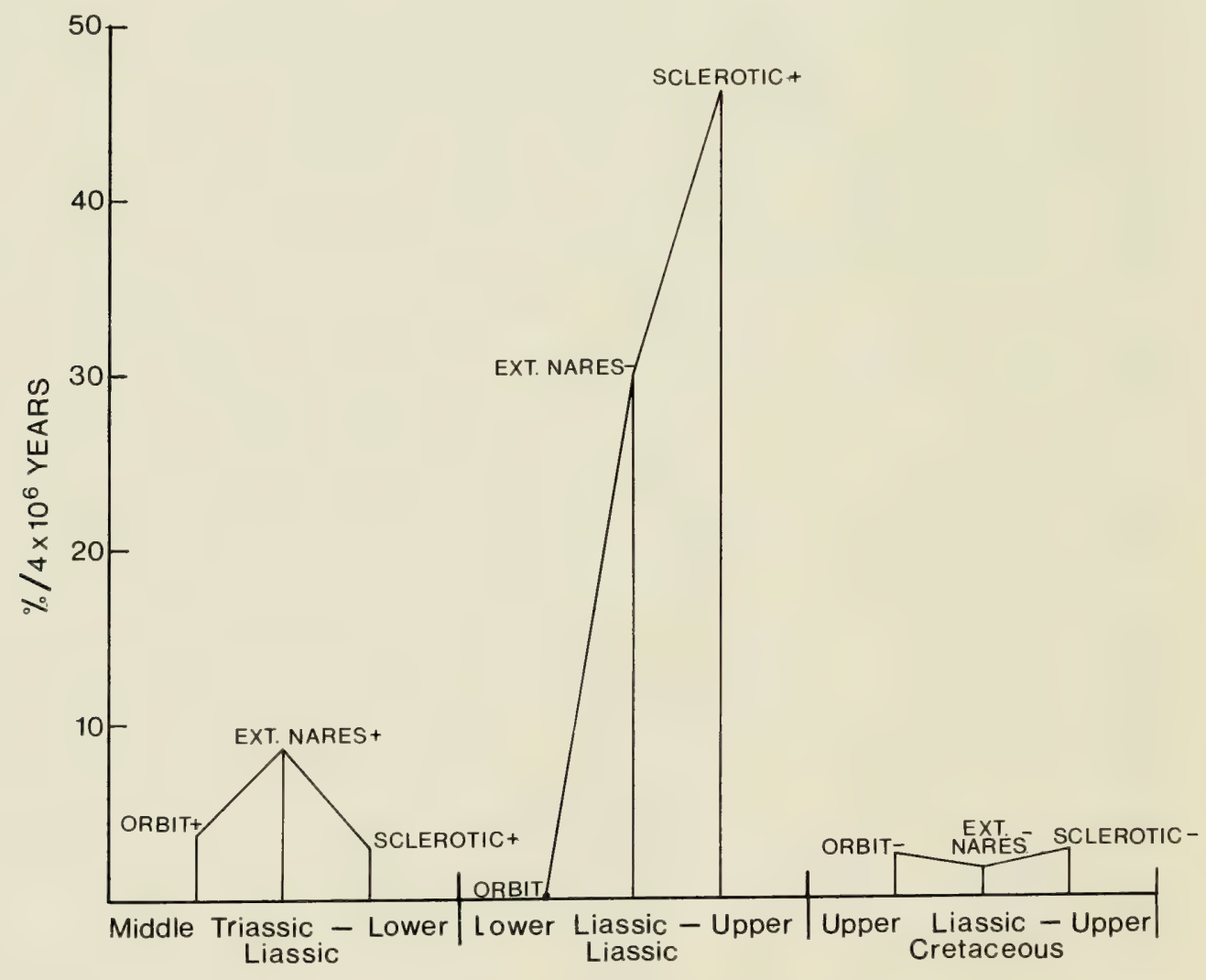

Fig. 15. Rates of cranial evolution with respect to percentage change in diameters of the orbit and internal sclerotic ring, and in the length of the external narial aperture, measured throughout each geological range. $+=$ increase in size; $-=$ decrease in size. 


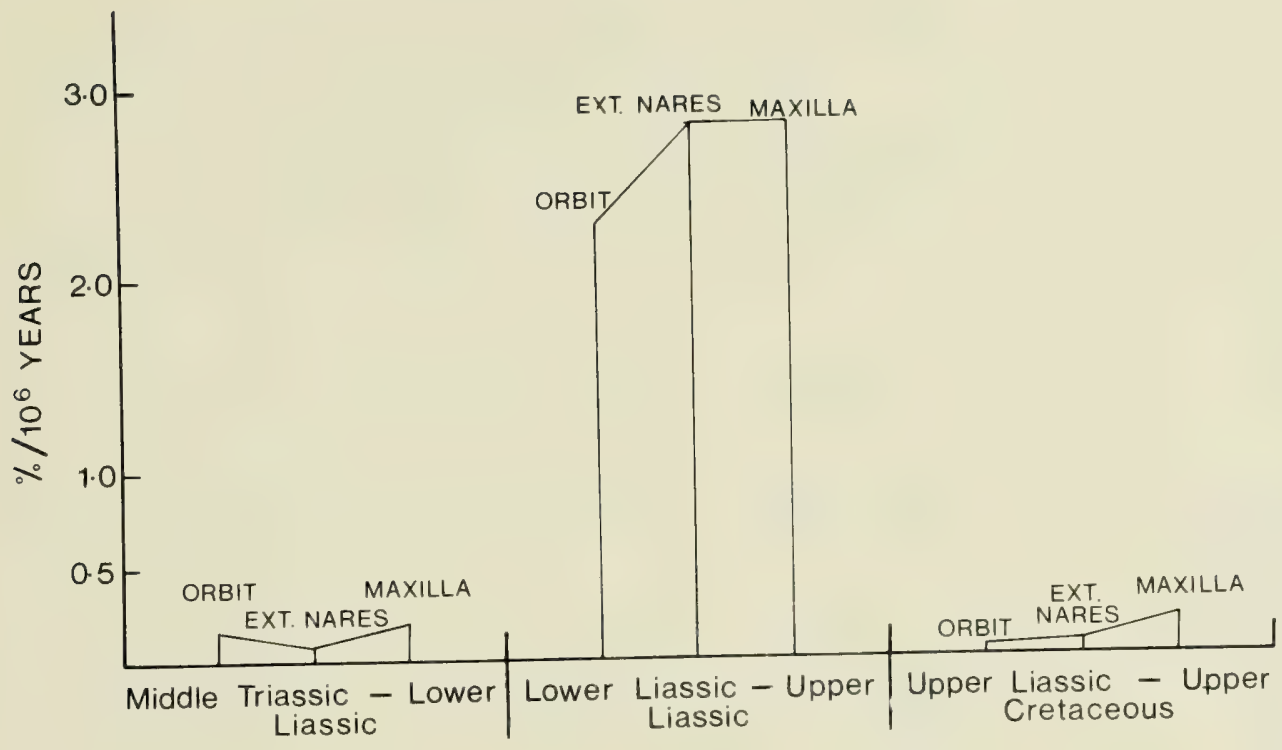

Fig. 16. Rates of cranial evolution with respect to the recession of the orbit, external narial aperture, and the anterior tip of the maxilla measured throughout each geological range.

16). For example, the diameter of the orbit remained unchanged during the Liassic interval but its rate of posterior recession was maximal. Furthermore, structures considered to have a close functional relationship did not always evolve at the same rate. Thus, the diameters of the orbit and internal sclerotic ring changed at about the same rate during the pre- and post-Liassic intervals but were dissimilar throughout the Liassic (Fig. 15). The well-marked trends toward an increase in orbital and internal sclerotic diameters, and in the size of the narial aperture, reversed after the Liassic (Fig. 15), and by the Cretaceous the three structures were relatively smaller than they had been even during the Triassic. These changes undoubtedly represent an example of the reversal of an evolutionary trend during a lineage. Not that such a reversal is without precedent in ichthyosaurs, for it was shown that the longipinnate fin, having undergone a reduction to four digits by the late Triassic, increased to five or more digits by the Liassic (McGowan, 1972). The fore fin of Platypterygius, with a total of eight digits, represents an extreme expression of this particular tendency. That the rate of cranial evolution was fastest during the Liassic and slowest during the postLiassic interval has been documented and is probably indicative of an overall slowing of the evolutionary process. This conclusion is corroborated by the homogeneity of body structure in Cretaceous ichthyosaurs.

\section{Evolution of the Longipinnate Body}

Because of the incompleteness of most of the skeletons and of the small sample sizes, conclusions drawn from available data are only tentative. Results are shown in Fig. 17, and five generalisations may be made: (1) the skull increased in length relative to the body; (2) the angle of the tail bend increased; (3) the pre-flexural segment of the tail decreased in length; (4) the post-flexural segment of the tail decreased in length; and (5) the length of the fore fins decreased. As only four species were 


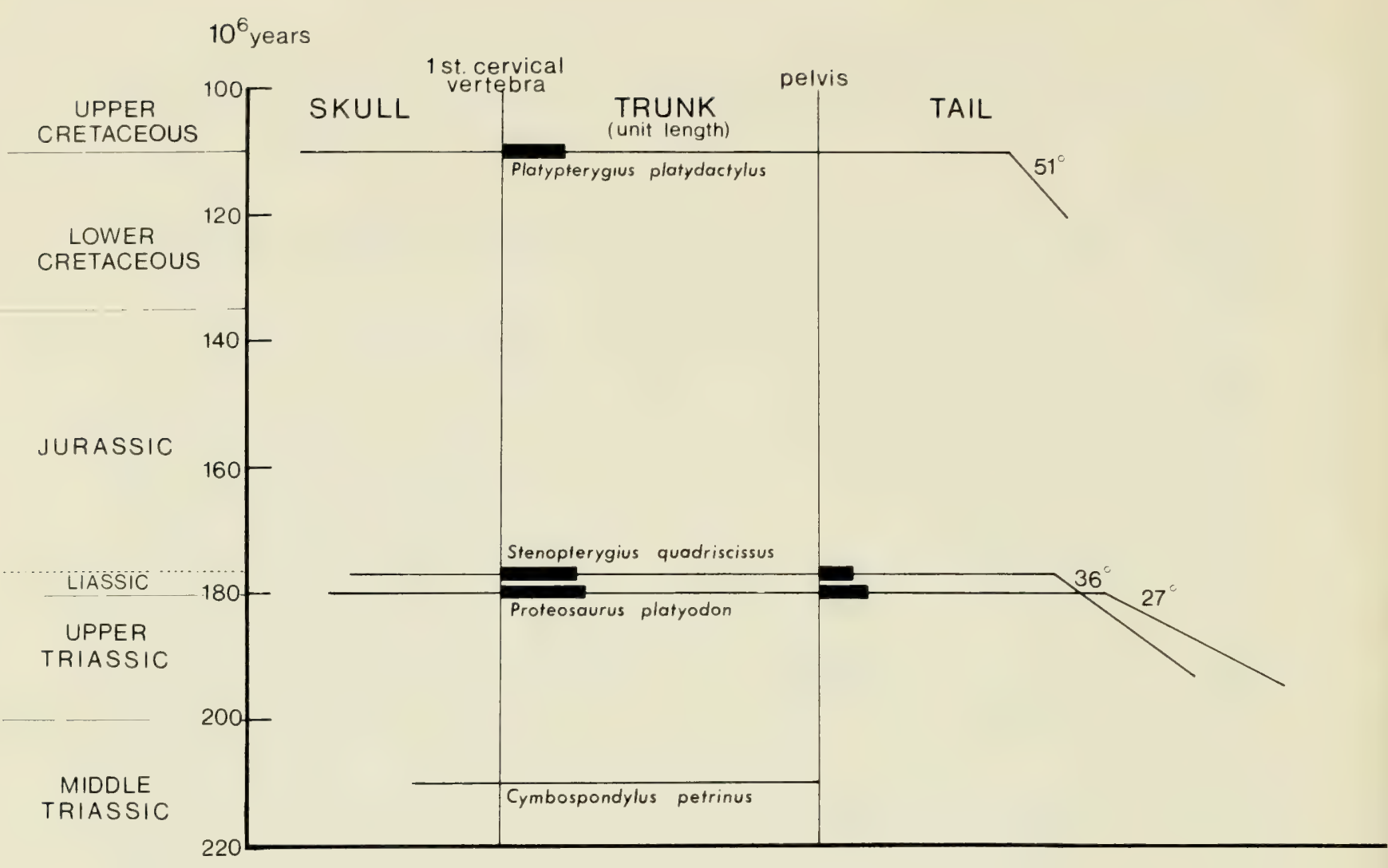

Fig. 17. Changes in body proportions of longipinnate ichthyosaurs during evolution. Data based on conversion of variates to linear foci, with trunk lengths the same. Black bars represent the icngth of fore and hind fins. Data for Cymbospondylus petrinus are incomplete.

Platypterygius platydactylus from Broili (1907, pl. 12).

Stenopterygius quadriscissus from Hauff (1953, pl. 9b).

Proteosaurus platyodon BMNH 2913.

Cymbospondylus petrinus UCM!P 9950.

studied, cross references were made to six other Upper Liassic longipinnates for which data was available (Fig. 18). How well do available data substantiate these generalisations?

1. Increase in length of skull

Skulls of the six other Upper Liassic longipinnates (Stenopterygius megalorhinus, S. megacephalus, S. crassicostatus, S. disinteger, S. acutirostris (?), and Eurhinosaurus longirostris, all from Hauff, 1953) were larger (relative to the body) than that of Cymbospondylus petrinus. Furthermore, with the exceptions of Stenopterygius quadriscissus and S. crassicostatus, the Upper Liassic longipinnates had larger skulls than the Lower Liassic Proteosaurus platyodon. The increase in relative skull length is thus well documented for the Middle Triassic-Upper Liassic period but is less well substantiated during the post-Liassic period. Thus, although skulls of S. quadriscissus, S. crassicostatus, and S. megalorhinus were smaller than that of Platypterygius platydactylus, the reverse was true for Eurhinosaurus longirostris and $S$. disinteger. Moreover, skulls of S. acutirostris (?) and S. megacephalus were comparable in size with that of Platypterygius platydactylus. It is concluded that the size of the skull increased relative to the body, and that this trend was most marked during the Middle Triassic-Lower Liassic 


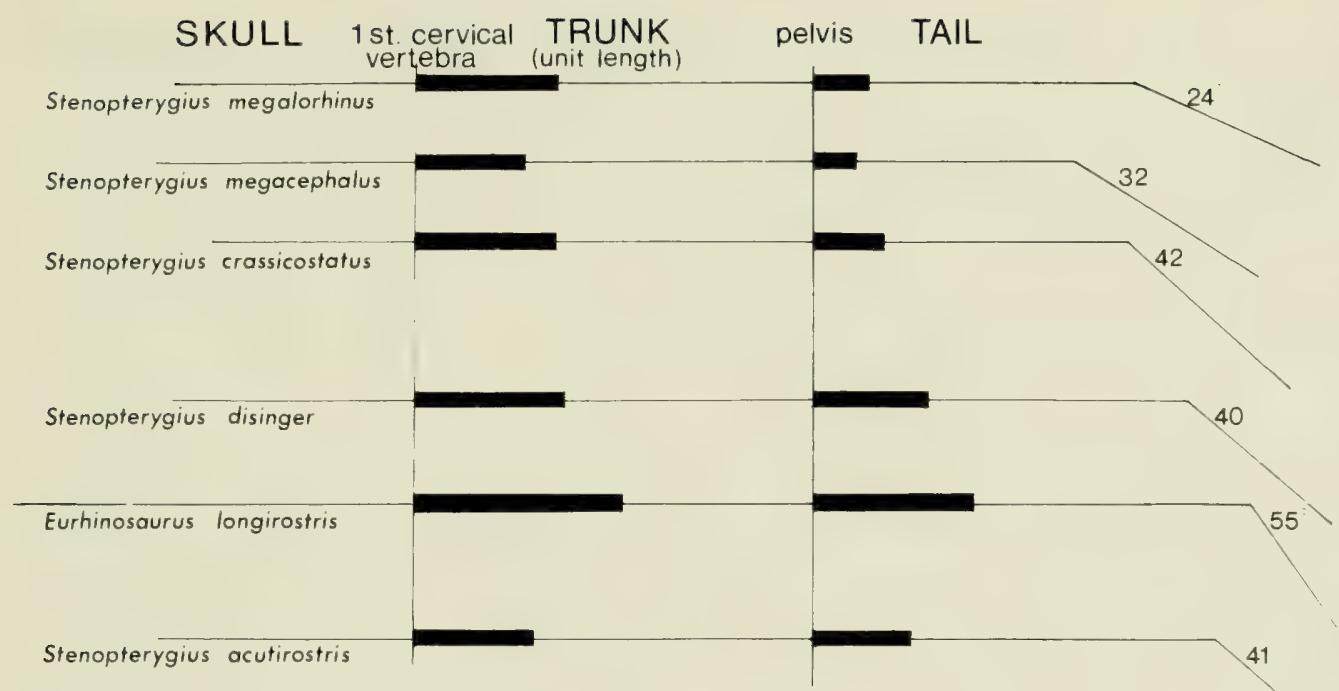

Fig. 18. Data of body proportions for Upper Liassic longipinnates based on conversion of variates to lincar foci. Black bars represent the lengths of fore and hind fins.

S. megalorhinits from Hauff (1953, pl. 13a).

S. megacephalus from Hauff (1953, pl, 12a).

S. crassicostatus from Hauff (1953, pl. 13b).

S. disinteger from Hauff (1953. pl. 18a).

Eurhinosaurus longirostris from Hauff (1953, pl. 21b).

S. acutirostris (?) from Hauff (1953, pl. 19b).

period. From the Upper Liassic to the Upper Cretaceous the tendency was apparent but less pronounced.

2. Increase in the angle of the tail bend

The angle of the tail bend was greater in Platypterygius platydactylus than in any of the Upper Liassic longipinnates except Eurhinosaurus. Furthermore, with the exception of Steopterygius megalorhinus, angles were greater in the Upper Liassic longipinnates than in the Lower Liassic species Proteosaurus platyodon. The conclusion is that there was an increase in the angle of the tail bend (a similar tendency occurred in the latipinnates).

3. Reduction in the pre-and post-flexural segments of the tail

All Upper Liassic longipinnates had longer pre- and post-flexural tail segments than did Platypterygius platydactylus and, with the exception of Eurhinosaurus, had shorter post-flexural segments than Proteosaurus platyodon. In the lengths of the pre-flexural segments, however, three of the Upper Liassic longipinnates ( $S$. disinteger, $S$. acutirostris(?), E. longirostris) exceeded $P$. platyodon. I therefore conclude that there was a general tendency for the tail segments to become shorter.

4. Reduction in fore fin

Although differences between the relative lengths of the fore fin of Proteosaurus platyodon, Stenopterygius quadriscissus, and Platypterygius platydactylus were not great, and although it is not certain whether the fore fin of the holotype of $P$. platydactylus was complete (Broili, 1907, 
fig. 13), the smallest fin was likely that of $P$. platydactylus. Furthermore, the fore fin in each of the six Upper Liassic longipinnates was relatively longer than in $P$. platydactylus. The trend toward a reduction in the length of the fore fin therefore appears to be substantiated.

\section{Evolution of the Longipinnate Fore Fin}

The lack of knowledge of the structure of the fore fin of Triassic ichthyosaurs was mentioned previously, and although the structure of the fore fin of Cymbospondylus petrinus (Middle Triassic) is not well known, that of the Upper Triassic species Merriamia zittelli is (Merriam, 1903). The fore fin of Merriamia consists of only three primary digits and a remnant of a fourth (Fig. 1E). The proximal carpal series comprises radiale, intermedium, and ulnare, and the distal carpal series contains three elements. From available evidence the fins of Toretocnemus and Delphinosaurus, both from the Upper Triassic, were probably similar (Merriam, 1908). Thus, by the late Triassic the longipinnate fore fin had undergone reduction from a previous pentadactyl condition (for a discussion of fore fins see McGowan, 1972). Information on fore fins is lacking until the early Liassic of England, where a few longipinnate species are recorded. Again, the fore fin possesses only three primary digits, but the individual elements have lost much of their earlier primitive appearance. The radius and ulna are relatively short, and the carpals and phalanges have become more oval. Several elements of the pre-axial series, including the radius, have emarginate free borders, and the retention of this seemingly primitive character (Lydekker, 1889, p. 70) is found throughout the Jurassic longipinnates.

By the late Liassic most longipinnates (Fig. 1F, G) had a digital count of five, due to the possession of accessory digits. All had retained a distal carpal series of three elements, and the total number of elements in each digit had increased. Probably all of the five-digits fins were broad-based (confirmed in several where the soft part of the fin is preserved as a carbonaceous film) and used exclusively as hydroplanes. The three-digit fins, on the other hand, tended to be long and narrow, as in S. acutirostris(?) and E. longirostris (Fig. 1F), and were probably used as paddles.

Nothing more of fore fin evolution is known until the Cretaceous and the appearance of Platypterygius. The acquisition of accessory digits had gone further in Platypterygius than in any other longipinnate and, for the first time in the known history of the Ichthyosauria, pre-axial accessory digits exceeded one in number (Fig. $1 \mathrm{H}$ ). Although the free borders of the radius and succeeding radial elements were not emarginate, many bones possessed small emarginations on their proximal and distal borders (see Nace, 1939; Nace, 1941; McGowan, in press, Contr. Geol.). As noted previously, the fin of Platypterygius was considered to have been a broad but narrow-based sculling structure. In the regular shapes of the phalanges and for their orderly arrangement in vertical rows, the fin was striking. 


\section{Size Ranges in Longipinnates}

Although the maximum attainable size in a given species cannot be predicted without a sufficiently large sample, taxa upon which the cranial discussion was based are each represented by at least three specimens and by many more in Upper Liassic species. Consequently, maximum attainable sizes could be estimated for 14 longipinnate species, which are

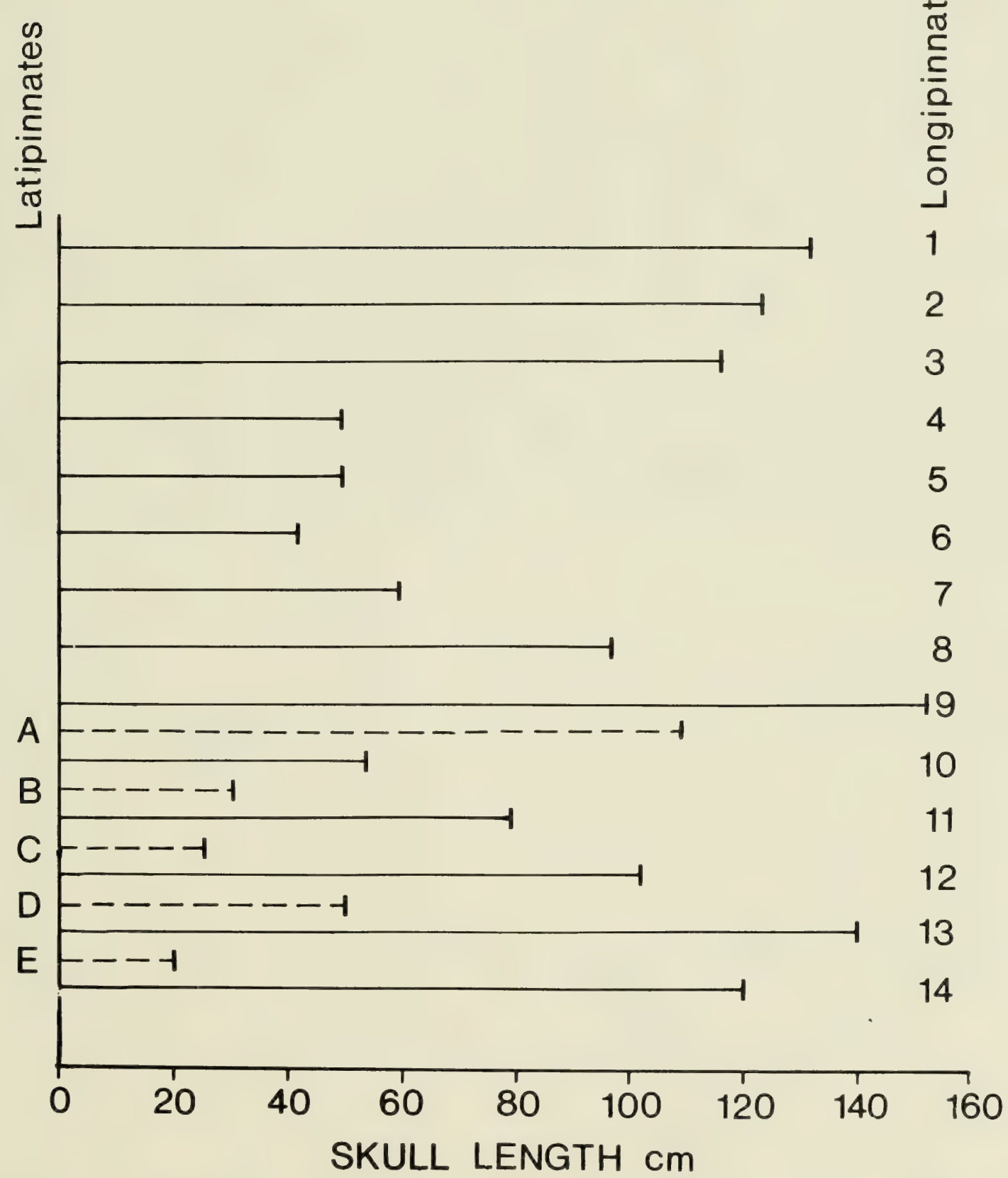

Fig. 19. Approximate maximum sizes of some ichthyosaur species determined from skull length. Latipinnates: A) Ophthalmosaurus; B) Ichthyosaurus conybeari; C) I. breviceps; D) I. communis; E) Mixosaurus cornalianus. Longipinnates: 1) Platypterygius australis; 2) P. americanus; 3) P. platydactylus; 4) Eurhinosaurus logirostris; 5) Stenopterygius megacephalus; 6) S. megalorhinus; 7) S. crassicostatus; 8) S. disinteger; 9) S. acutirostris (?); 10) S. quadriscissus; 11) Proteosaurus sp.* (undescribed new species from the Lower Liassic of England); 12) Proteosaurus sp. (a second undescribed new species); 13) Proteosaurus platyodon; 14) Cymbospondylus petrinus. 
compared with five latipinnate species (Fig. 19). In general, longipinnates always tended to be large and were much larger than their latipinnate counterparts. Based only on skull lengths Cymbospondylus petrinus was not the largest longipinnate, for its skull was only about half as long relative to its body as that of Proteosaurus platyodon. But in total body length, $C$. petrinus was probably the largest known ichthyosaur, reaching at least 10 metres. $P$. platyodon probably did not greatly exceed 9 metres in length. Except for Stenopterygius acutirostris (?), a veritable giant of nearly 8 metres (Hauff, 1953, pl. 19), the Upper Liassic longipinnates were smaller than $P$. platyodon, usually less than 4 metres in length. Relative to its body, the skull of Platypterygius platydactylus was slightly more than twice as large as that of $C$. petrinus (see Fig. 17). Although the skull of $P$. platydactylus was about the same size as that of $C$. petrinus, in total body length $P$. platydactylus was probably only about 7 metres but, even so, larger than any Upper Liassic longipinnate. Complete data from the Upper Triassic longipinnates is wanting, but species of the genus Shastasaurus were probably the same size as $C$. petrinus, whereas the size of Delphinosaurus perrini was comparable to that of Upper Liassic species, e.g., Stenopterygius quadriscissus. Merriamia zittelli and Toretocnemus californicus were both small species, probably only one metre long, and were therefore the smallest of all longipinnates. It is conceivable, however, that the material referred to these two species represents immature individuals. 


\section{Conclusions}

When ichthyosaurs first appeared in the fossil record, in the Middle Triassic, they were already highly adapted to an aquatic mode of life and were represented by two distinct stocks, the latipinnates and the longipinnates. Latipinnate ichthyosaurs always tended to be moderate in size, generally not exceeding 4 metres in total body length, whereas the longipinnate stock produced some giants, including Cymbospondylus petrinus (Middle Triassic) the largest of ichthyosaurs with an estimated adult body length of about 10 metres. From the available evidence it appears that the longipinnates survived to the late Cretaceous, whereas the latipinnates had become extinct by the late Jurassic (Fig. 20). The longipinnates appear to have evolved most rapidly during the early part of the Jurassic, but after this period the evolutionary process slowed to its lowest rate. The changing rates of evolution during the history of the longipinnates may have been correlated with changes in food availability. The

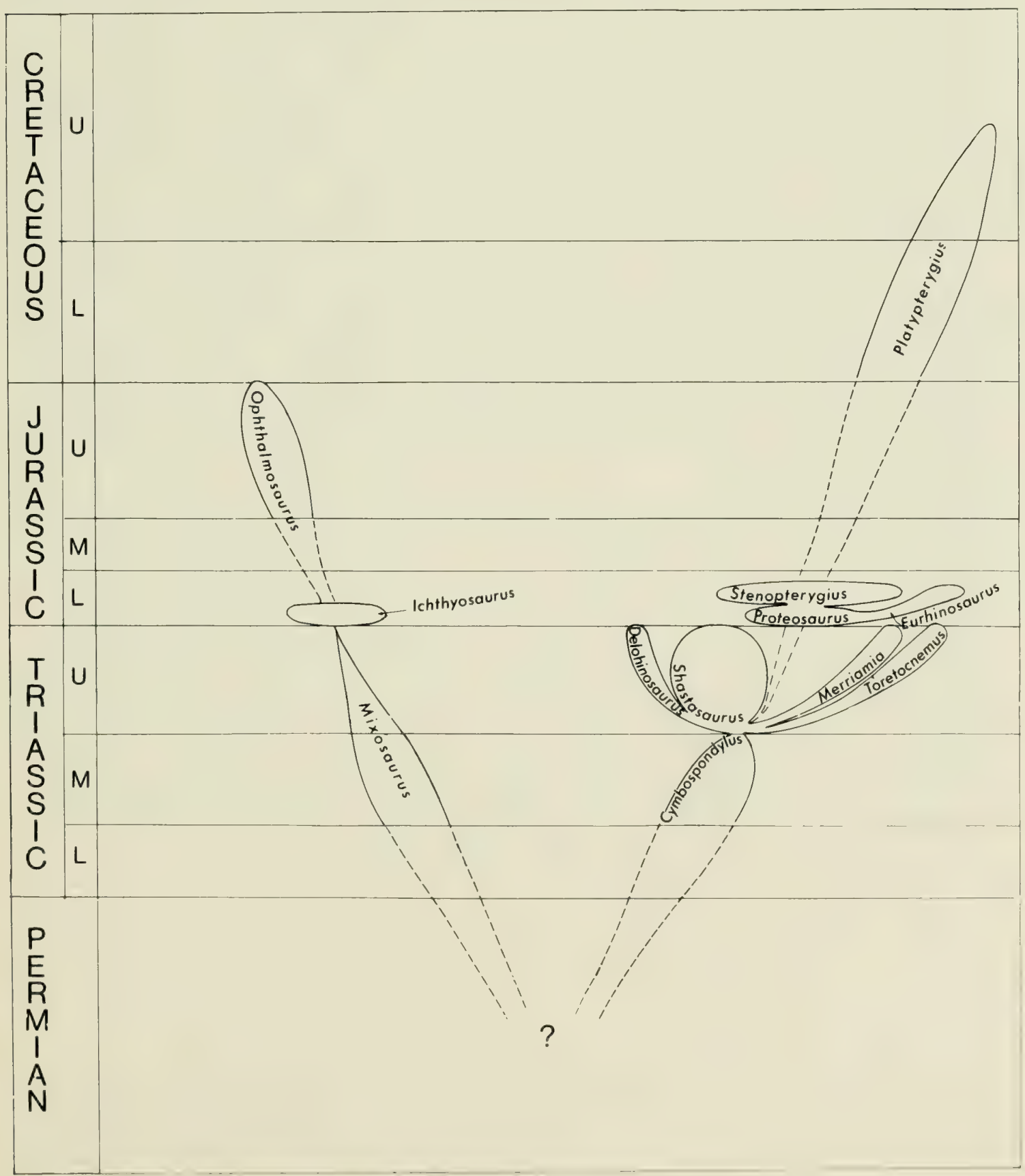

Fig. 20. A phylogeny of the Ichthyosauria. 
diet of Triassic ichthyosaurs is unknown, and they may have fed on fishes and cephalopods (e.g., belemnites, ammonites, and squids, all of which were becoming increasingly more abundant) and perhaps also on other marine reptiles, e.g., placodonts. Fishes and cephalopods were not as abundant during the Triassic as they were to become by the Liassic, and the relatively low rate of evolution and paucity of ichthyosaurian remains during the Triassic could be attributable to limited food resources. Liassic ichthyosaurs fed on holostean fishes of the genera Lepidotes, Dapedium, and Pholidophorus, as well as on belemnites and ammonites (Pollard, 1968; McGowan, in press, Bull. Br. Mus.). The Liassic seas abounded with these prey, and the Liassic was therefore a time of plenty for ichthyosaurs. The rapid rate of evolution and the abundance of ichthyosaur remains during the Liassic may therefore be attributable to optimum environmental conditions. By Cretaceous times the marine fauna had changed considerably, but there is no reason to suppose that the seas were any less bountiful than they had been during the Liassic. Teleosts had largely replaced holostean fishes, and the advanced selachians had undergone an adaptive radiation. Ammonites and squids were even more plentiful than they had been during the Liassic and, assuming a diet of fishes, belemnites, ammonites, and squids, opportunities for ichthyosaurs were probably no less during the Cretaceous. Why, then, was the rate of evolution during the Cretaceous so low, and why were ichthyosaurs relatively scarce? A failure of the fossil record might be a plausible explanation, for Lower Cretaceous marine deposits are not abundant. But the complete absence of ichthyosaurs from the rich Niobrara chalk deposits of the Upper Cretaceous of the western U.S. (Romer, 1966) and the remarkable homogeneity of all Cretaceous ichthyosaurs thus far recovered (McGowan, in press, Contr. Geol.) give convincing evidence that the group was indeed in decline, and an explanation must be sought.

The slowing of evolutionary rates during the post-Liassic period may be correlated with the prevalence of more constant environmental conditions. By the Cretaceous selachians had completed much of their evolution and were essentially similar to the present fauna. Ammonites, belemnites, and squids still abounded, and populations were relatively stable. But the bony fish fauna had not attained stability because the teleosts were diversifying rapidly and replacing the holosteans. There are therefore some grounds for concluding that a greater stability existed in the marine environment during the Cretaceous. Although greater environmental stability may have been a contributing factor to the slowing rate of evolution, it was probably not the only one. Perhaps some genetic changes occurred during the long post-Liassic interval, thereby reducing variation. This suggestion is at present the most attractive one because it leads to an hypothesis for the ultimate extinction of the ichthyosaurs which will now be examined.

As far as can be established from the fossil record, Platypterygius was the sole representative of the Ichthyosauria in Cretaceous times. There is no evidence of any other genera, and species referred to Platypterygius 
appear to be very similar. Adults probably reached body lengths of about 7 metres, and the propulsive thrust of the small tail was augmented by the the fore fins (probably also the hind fins), perhaps a less efficient swimming mechanism than that of Liassic longipinnates. Whereas a loss of swimming efficiency may have been inconsequential during the early Cretaceous, it may have become critical by late Cretaceous times when ichthyosaurs were faced with increased competition from plesiosaurs and new competition from mosasaurs. Plesiosaurs derived their propulsive thrust from their fore and hind paddles, the extensive musculature of which is reflected in the large size of the girdles. Mosasaurs, on the other hand, derived their propulsive thrust from lateral undulations of the elongate body and deep tail. (The paddles were almost certainly pressed against the body during forward motion, as in extant swimming lizards, and were used only when stationary.) Thus, both plesiosaurs and mosasaurs employed only one method to produce a forward thrust, while Platypterygius practised a division of labour. Consequently, Platypterygius may have been outclassed by its reptilian contemporaries in speed, manoeuverability, or diving abilities. Nonetheless, caution should be exercised when drawing conclusions on locomotory prowess from evidence of the skeleton alone. The aquatic performance of the otter (Lutra), for example, is incredible, but there is little or no skeletal evidence to indicate that the otter is so agile. With reservations, then, it is concluded that Platypterygius might have been less efficient in its locomotory abilities than the plesiosaurs and mosasaurs.

Mosasaurs did not appear until late in the Cretaceous and then underwent a rapid proliferation. At that time the ichthyosaurs were apparently at an evolutionary standstill. Perhaps the reason for the eventual demise of the ichthyosaurs should be sought in a loss of adaptive plasticity at a time when a new competitor was undergoing adaptive radiation. Although this hypothesis may satisfactorily explain the final extinction of the ichthyosaurs, the disappearance of the smaller longipinnates (e.g., Stenopterygius quadriscissus) that had been so successful during the early Jurassic remains unresolved. One would imagine that there has always been an ecological niche for such animals, one today occupied by the dolphins (Delphinoidea). Perhaps stenopterygians were extant during the Cretaceous but lived in environments different from those occupied by the platypterygians and were excluded from the fossil record. A parallel exists in the Upper Liassic; remains of latipinnates are apparently absent, even though they are found in Lower Liassic and in Upper Jurassic deposits. Only more Cretaceous material will resolve this point. 


\section{Acknowledgments}

I wish to thank Dr. Alan Charig and Mr. Cyril Walker of the British Meseum (Natural History), and Dr. C. L. Forbes of the Sedgwick Museum, Cambridge, and Mr. J. M. Edmonds and Mr. H. P. Powell of the Oxford University Museum for their generous help in making material available for study. I thank Drs. M. Wade and A. Bartholomai of the Queensland Museum for generously supplying me with material, photographs, and a considerable amount of data. I wish also to thank Drs. K. N. Bell of the National Museum of Victoria and D. Rhodes of the University of Western Australia for supplying photographs and Drs. D. Merrilees of the Western Australian Museum and A. Ritchie of the Australian Museum, Sydney, for supplying information. For the loan of material and warm hospitality, I thank Drs. S. P. Welles and J. T. Gregory of the University of California, Berkeley, and Paul McGrew of the University of Wyoming.

Thanks are also due to Miss Lynda Smith and Mrs. Judy Allan for their continued assistance, Mrs. Sophie Poray for drawing the figures, Miss E. Dowie and Mrs. P. Trunks of the ROM Library, and Mr. L. Warren and staff of the ROM Department of Photography. I also thank Dr. A. G. Edmund for reading the manuscript and for advice. 


\section{Literature Cited}

ANDREWS, C. W.

1910 A descriptive catalogue of the marine reptiles of the Oxford clay. Part 1. London, Printed by Order of the Trustees of the British Museum. $205 \mathrm{pp}$.

BROILI, F.

1907 Eine neuer Ichthyosaurus aus der norddeutschen Kreide. Palaeontographica, vol. 54, pp. 139-162.

1931 Mixosauridae von Timor. Wet. Meded. Dienst Mijnb. Ned.-Oost-Indië, no. 17, pp. 3-10.

HAUFF, B.

1953 Das Holzmadenbuch. Ohringen, Verlag der Hohenlohe' schen Buchlandlung. $54 \mathrm{pp}$.

HUENE, F. VON

1936 Ichthyosaurierreste aus Timor. Zentbl. Miner. Geol. Paläont., abt. B, HULKE, J. W. pp. 327-334.

1873 Memorandum on some fossil vertebrate remains collected by the Swedish expeditions to Spitzbergen in 1864 and 1868. Bih. K. Svenska VetenskAkad. Handl., n.s., band 1, no. 9, pp. 2-11.

KUHN, 0.

1946 Ein skelett von Ichthyosaurus (Platypterygius) hercynicus n. sp. aus dem Aptium von gitter. Ber. Naturf. Ges. Bamberg. vol. 29, pp. 69-82.

LYDEKKER, R.

1889 Catalogue of fossil Reptilia and Amphibia in the British Museum (Natural History). Part 2. Containing the orders Ichthyopterygia and Sauropterygia. London, Printed by Order of the Trustees of the British Museum. 307 pp.

MCGOWAN, C.

1969 The cranial morphology and interrelationships of the Lower Liassic ichthyosaurs. Ph. D. thesis, University of London. 498 pp.

1972 The distinction between latipinnate and longipinnate ichthyosaurs. Life Sci. Occ. Pap., R. Ont. Mus., no. 20, pp. 1-12.

In The cranial morphology of the Lower Liassic latipinnate ichthyosaurs press of England. Bull. Br. Mus. Nat. Hist. Geol.

In The systematics of Cretaceous ichthyosaurs with particular reference press to the material from North America. Contr. Geol.

MCWAE, J. R. H., P. E. PLAYFORD, A. W. LINDNER, B. F. GLENISTER and B. E. BALME

1958 The stratigraphy of Western Australia. Carlton, Victoria, Melbourne University Press on behalf of the Geological Society of Australia. $161 \mathrm{pp}$.

MERRIAM, J. C.

1903 New Ichthyosauria from the Upper Triassic of California. Univ. Calif. Publs. Bull. Dep. Geol., vol. 3, no. 12, pp. 249-263.

1906 Preliminary note on a new marine reptile from the Middie Triassic of Nevada. Univ. Calif. Publs. Bull. Dep. Geol., vol. 5, no. 5, pp. 75-79.

1908 Triassic Ichthyosauria, with special reference to the American forms. Mem. Univ. Calif., vol. 1, no. 1, pp. 1-196.

1910 The skull and dentition of a primitive ichthyosaurian from the Middle Triassic. Univ. Calif. Publs. Bull. Dep. Geol., vol. 5, no. 24, pp. 381-390. MERRIAM, J. C. and H. C. BRYANT

1911 Notes on the dentition of Omphalosaurus. Univ. Calif. Publs. Bull. Dep. Geol., vol. 6, no. 14, pp. 329-332. 
NACE, R. L.

1939 A new ichthyosaur from the Upper Cretaceous Mowry Formation of Wyoming. Am. J. Sci., vol. 237, no. 9, pp. 673-686.

1941 A new ichthyosaur from the Late Cretaceous, northeast Wyoming. Am. J. Sci., vol. 239, no. 12, pp. 908-914.

POLLARD, J. E.

1968 The gastric contents of an ichthyosaur from the Lower Lias of Lyme Regis, Dorset. Paleontology, vol. 11, pt. 3, pp. 376-388.

ROMER, A. S.

1966 Vertebrate Paleontology. 3d. ed. Chicago, University of Chicago Press. $468 \mathrm{pp}$.

1968 An ichthyosaur skull from the Cretaceous of Wyoming. Contr. Geol. vol. 7 , no. 1 , pp. 27-41.

RUSCONI, C.

1948 Ictiosaurios del Jurásico de Mendoza (Argentina). Revta. Mus. Hist Nat. Mendoza, vol. 2, entregas 1-2, pp. 17-162.

TARLO, L. B.

1958 The scapula of Pliosaurus macromerus Phillips. Palaeontology, vol. 1. pt. 3, pp. 193-199.

TEICHERT, C., and R. S. MATHESON

1944 Upper Cretaceous ichthyosaurian and plesiosaurian remains from Western Australia. Aust. J. Sci., vol. 6, no. 6, pp. 167-170.

UNDERWOOD, G.

1970 The eye. In Gans, C. ed. Biology of the Reptilia. vol. 2. Morphology B. London, Academic press, pp. 1-97.

WIMAN, C.

1910 Ichthyosaurier aus der Trias Spitzbergen. Bull. Geol. Instn. Univ. Upsala, vol. 10, pp. 124-148.

1916 Notes on the marine Triassic reptile fauna of Spitzbergen. Univ. Calif. Publs. Bull. Dep. Geol., vol. 10, no. 5, pp. 63-73.

1929 Eine neue marine Reptilien-Ordnung aus der Trias Spitzbergens. Bull. Geol. Instn. Univ. Upsala, vol. 22, no. 5, pp. 183-196.

1933 Uber Grippia longirostris. Nova Acta R. Soc. Sci. Upsal., ser. 4, vol. 9. no. 4 , pp. 1-19 



